\title{
Natural Resource Management Plan for Brookhaven National Laboratory
}

Environmental Protection Division

Brookhaven National Laboratory

Operated by

Brookhaven Science Associates

Upton, NY 11973-5000 
This report was prepared as an account of work sponsored by an agency of the United States Government. Neither the United States Government nor any agency thereof, nor any of their employees, nor any of their contractors, subcontractors or their employees, make any warranty, express or implied, or assumes any legal liability or responsibility for the accuracy, completeness, or any third party's use or the results of such use of any information, apparatus, product, or process disclosed, or represents that its use would not infringe privately owned rights. Reference herein to any specific commercial product, process, or service by trade name, trademark, manufacturer, or otherwise, does not necessarily constitute or imply its endorsement, recommendation, or favoring by the United States Government or any agency thereof or its contractors or subcontractors. The views and opinions of authors expressed herein do not necessarily reflect those of the United States Government or any agency thereof. 


\section{Preface}

This comprehensive Natural Resource Management Plan (NRMP) for Brookhaven National Laboratory (BNL) was built on the successful foundation of the Wildlife Management Plan for BNL, which it replaces. This update to the 2003 plan continues to build on successes and efforts to better understand the ecosystems and natural resources found on the BNL site. The plan establishes the basis for managing the varied natural resources located on the 5,265 -acre BNL site, setting goals and actions to achieve those goals. The planning of this document is based on the knowledge and expertise gained over the past 10 years by the Natural Resources management staff at BNL in concert with local natural resource agencies including the New York State Department of Environmental Conservation, Long Island Pine Barrens Joint Planning and Policy Commission, The Nature Conservancy, and others. The development of this plan is an attempt at sound ecological management that not only benefits BNL's ecosystems but also benefits the greater Pine Barrens habitats in which BNL is situated. This plan applies equally to the Upton Ecological and Research Reserve (Upton Reserve). Any difference in management between the larger BNL area and the Upton Reserve are noted in the text. 


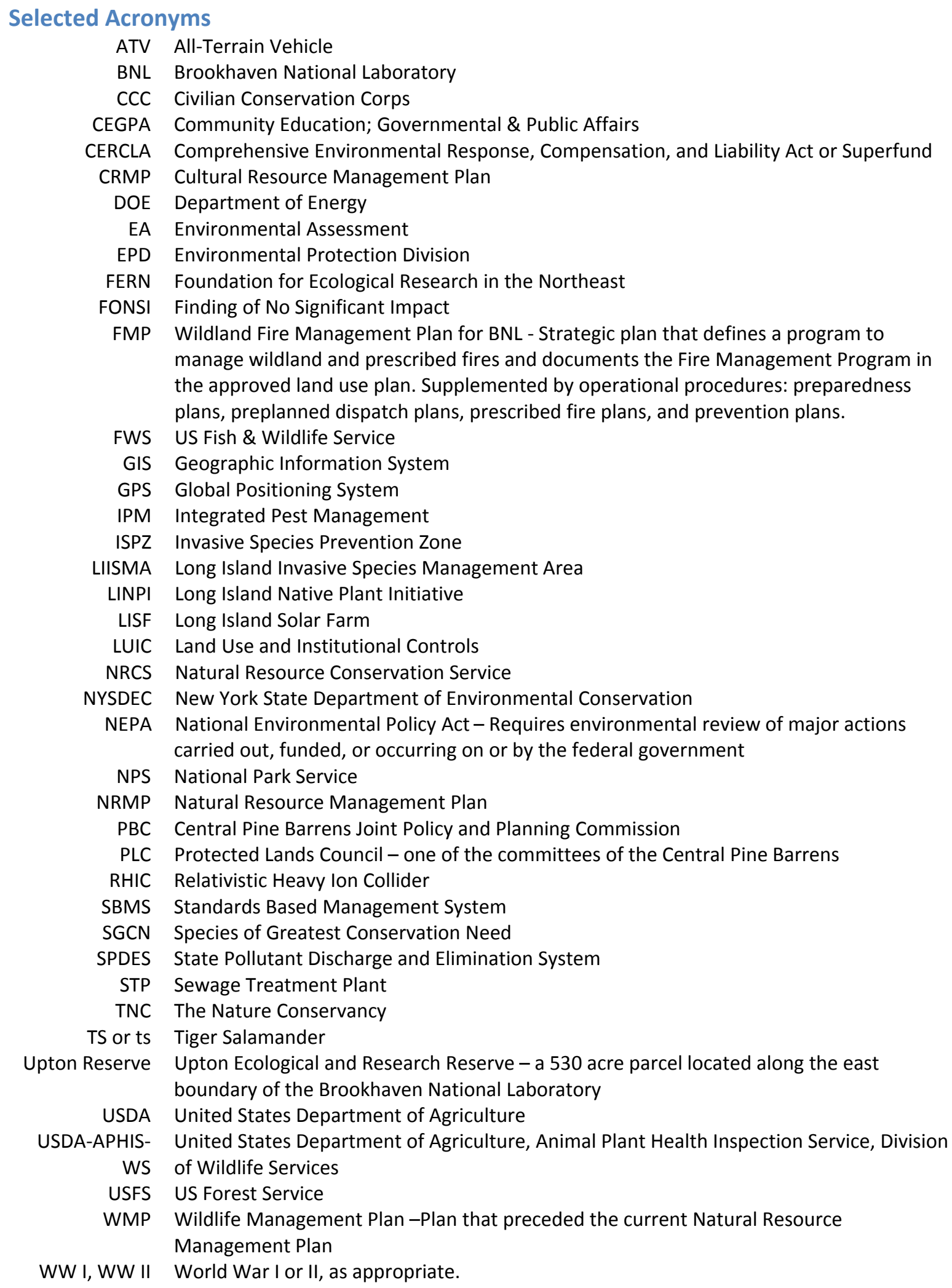




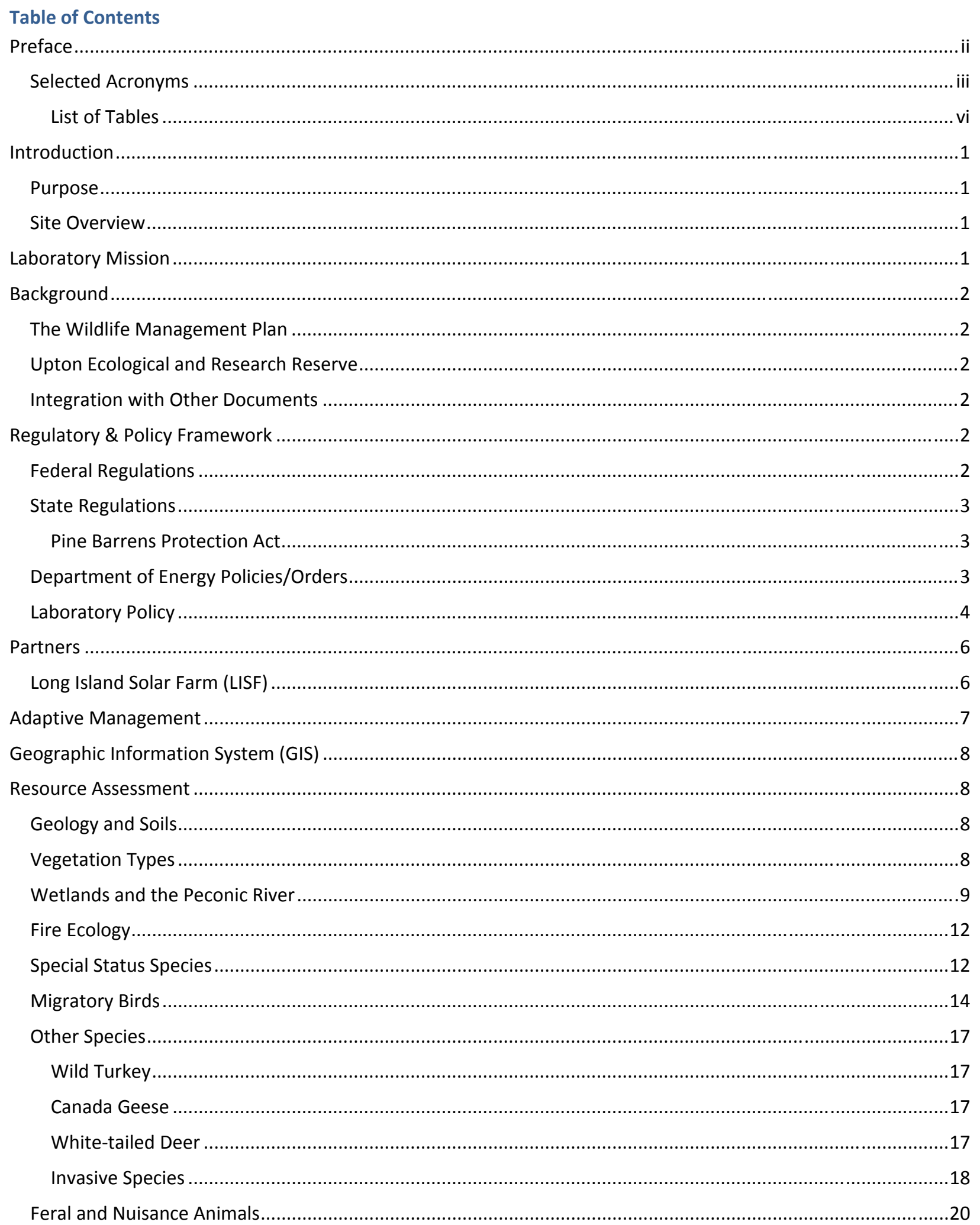




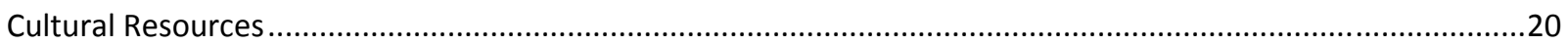

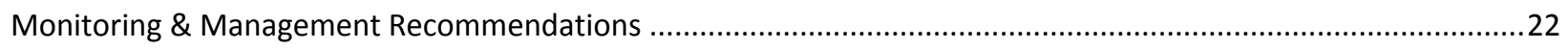

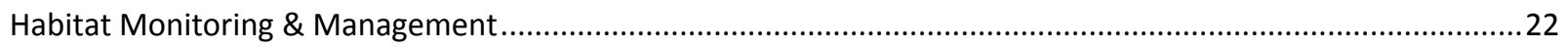

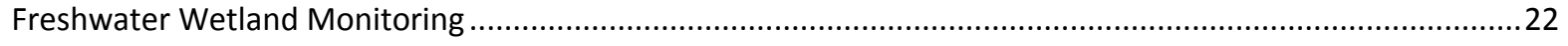

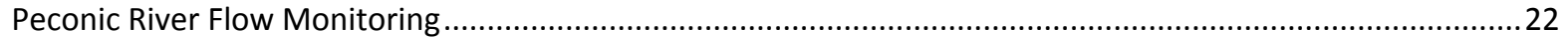

Operable Unit (OU) V Peconic River Remediation Program ...................................................................22

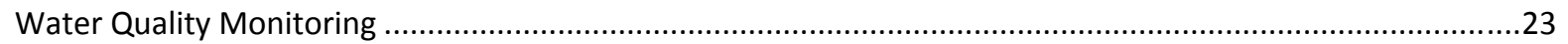

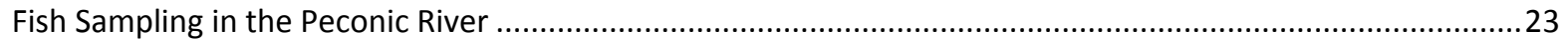

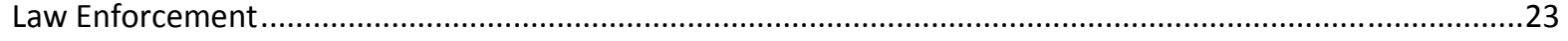

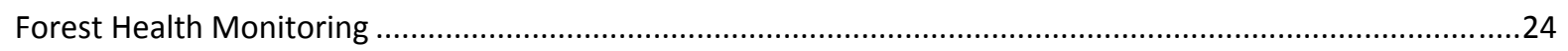

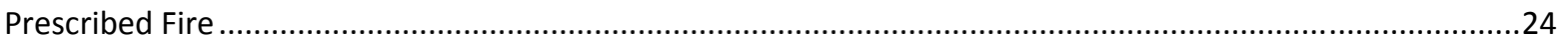

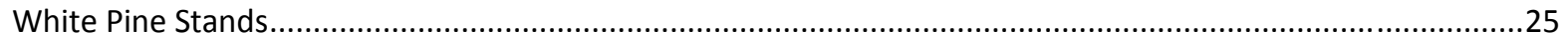

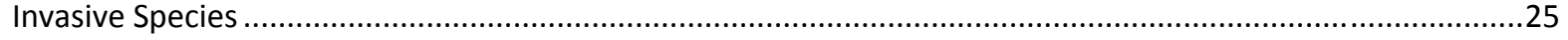

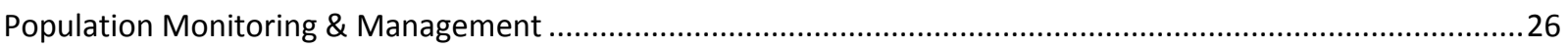

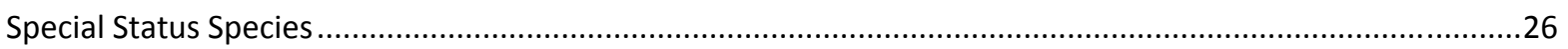

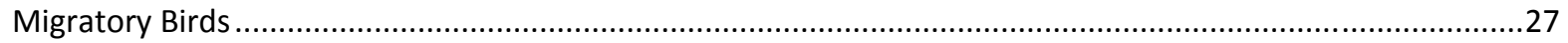

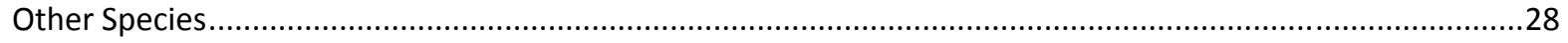

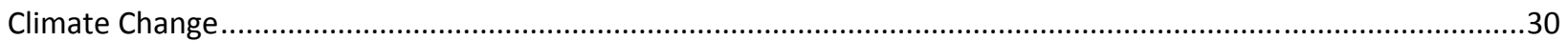

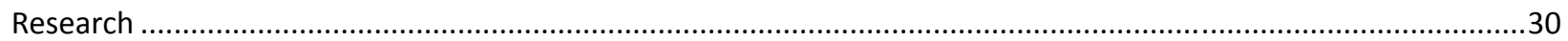

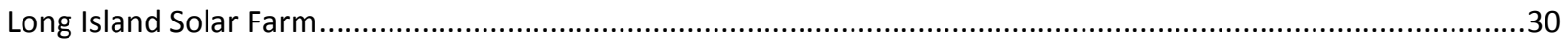

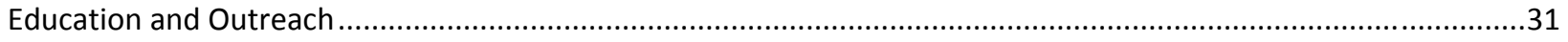

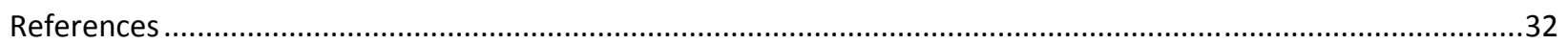

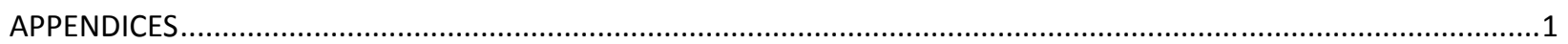

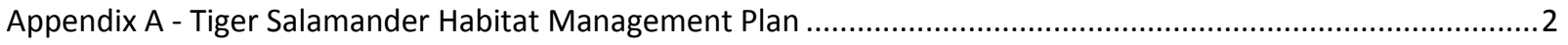

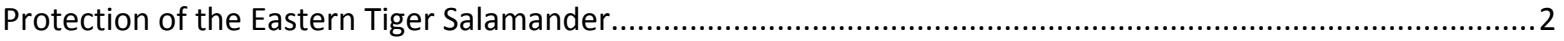

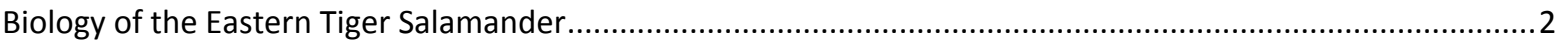

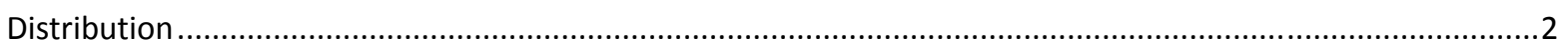

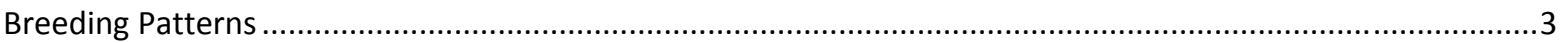

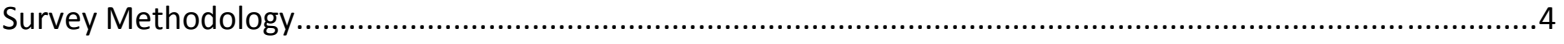

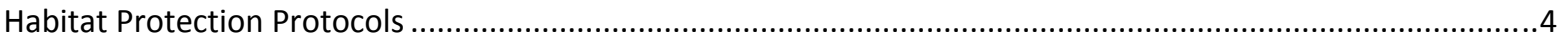

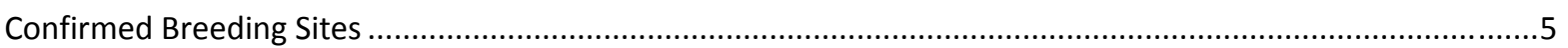

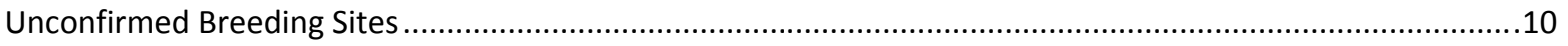

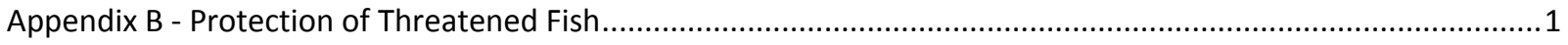

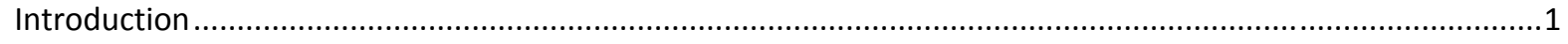

Protection or Enhancement of Threatened Fish Habitat..........................................................................

Appendix C - Natural Resource Management Plan - Completed Action Items...............................................

Appendix D - Natural Resource Management Plan - Ongoing and New Action Items ..................................... 
List of Tables

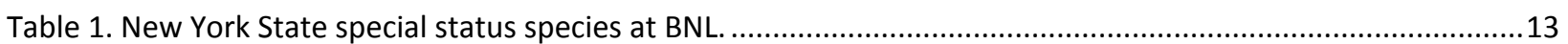

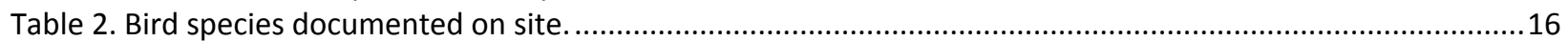

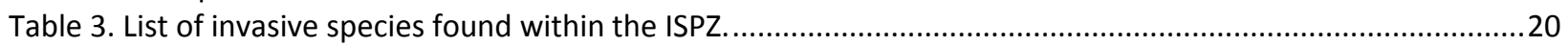

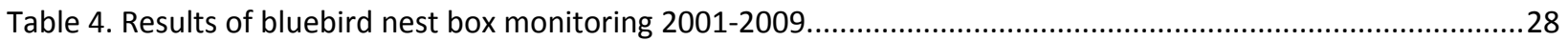

\section{List of Figures}

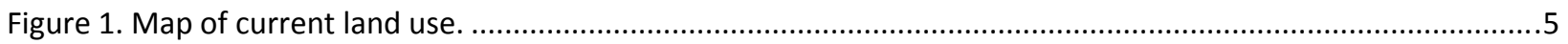

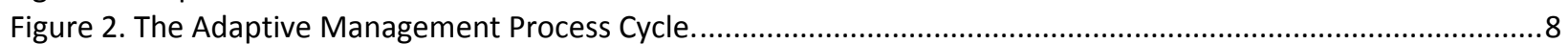

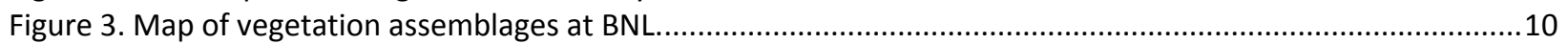

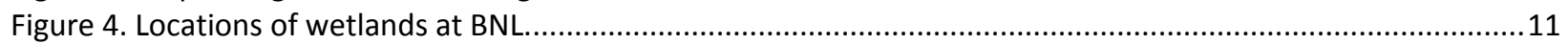

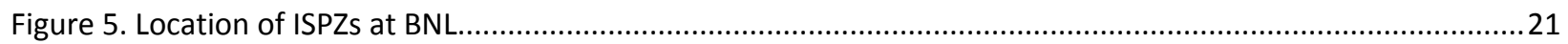

Figure 6 . Bluebird nest box use based on a percentage of available boxes. ....................................................28 


\section{Introduction}

\section{Purpose}

The purpose of the Natural Resource Management Plan (NRMP) is to provide management guidance, promote stewardship of the natural resources found at BNL, and to sustainably integrate their protection with pursuit of the Laboratory's mission. The philosophy or guiding principles of the NRMP are stewardship, sustainability, adaptive ecosystem management, compliance, integration with other plans and requirements, and the incorporation of community involvement, where applicable.

The NRMP is periodically reviewed and updated, typically every five years. This review and update was delayed to develop documents associated with a new third party facility, the Long Island Solar Farm. This two hundred acre facility will result in significant changes to this plan warranting the delay. The body of this plan establishes the management goals and actions necessary for managing the natural resources at BNL in a sustainable manner. The appendices provide specific management requirements for threatened and endangered amphibians and fish (Appendices $A$ and $B$, respectively), and lists of actions in tabular format-including completed items as well as ongoing and new action items (Appendices $C$ and $D$, respectively).

\section{Site Overview}

BNL is a 5,265-acre site located in the heart of the Central Pine Barrens on Long Island, New York, approximately 60 miles east of New York City and 60 miles west of Montauk Point. Long Island is approximately 120 miles long, east-west, and 20 miles wide at its widest point. The terrain on Long Island is relatively flat and low except along the north shore. Elevation ranges from sea level to $120 \mathrm{feet}$, with the highest points occurring on east-west moraines along the north shore and the midsection of Long Island. Topography south and east of the moraines is generally flat with a south-facing slope; this description characterizes the BNL site.

Roughly 1,450 acres of the BNL site are developed for Laboratory work, leaving about 3,615 acres as undeveloped woodland. The neighboring communities are predominantly residential developments scattered among wooded acreage. Many of the neighborhoods are virtually hidden by screens of overgrown, vine-covered woodland that lines most of the roads and highways. The majority of the woods is not maintained and contains significant amounts of surface litter (i.e. leaves and other partially decomposed organic matter).

\section{Laboratory Mission}

BNL is a multi-program national laboratory managed by Brookhaven Science Associates for the U.S. Department of Energy (DOE). BNL was founded in 1947, and is located on land formally operated as Camp Upton by the U.S. Army. BNL is in Suffolk County, New York, and is approximately 60 miles east of New York City.

The Lab's vision is to be the "provider of choice" for world-class science and facilities, in support of the DOE Office of Science and its mission to enable breakthroughs that ensure a successful future for our nation. To us, this means excellence in all aspects of our work - from science, to safety, to project management, and more.

From the Laboratory's perspective, the site mission is focusing on two broad areas of research. The first is advancing photon sciences and energy-related research and applying them to 21st-Century problems of critical importance to the nation. The second is advancing fundamental research in nuclear and particle physics to gain a deeper understanding of matter, energy, space, and time.

BNL makes its unique facilities, technical expertise, and the natural environment within its facility available to state and federal agencies, universities, and the private sector to conduct research in a manner that is consistent with these missions. 


\section{Background}

\section{The Wildlife Management Plan}

In the mid-1990s BNL began developing a wildlife management program. This program was guided by the Wildlife Management Plan (WMP), which was reviewed and approved by various state and federal agencies in September 1999. The WMP primarily addressed concerns with the protection of New York State threatened and endangered species, or species of concern, as well as deer populations, invasive species management, and the revegetation of the area surrounding the Relativistic Heavy lon Collider (RHIC). The WMP provided a strong and sound basis for wildlife management and established a basis for the development of the NRMP, which will guide the natural resource management program for BNL. All applicable actions found within the former WMP were incorporated within the first NRMP and these actions will continue to be updated and implemented under the new plan as necessary.

\section{Upton Ecological and Research Reserve}

As the Department of Energy funding for the Upton Reserve was reaching its agreed end date, the DOE, Pine Barrens Commission, and the Laboratory worked to establish a not-for-profit organization to carry-on the work of the Upton Reserve. The Foundation for Ecological Research in the Northeast (FERN) was incorporated in New York on Nov. 25, 2003 and implemented the first ever forest health monitoring of the Central Pine Barrens in CY2005 using funding secured in CY2004. FERN's board of directors represent interests of BNL, The Nature Conservancy, Stony Brook University, and Dowling College with board seats for up to 15 members. FERN and the Natural Resource Program at BNL are closely allied to ensure sound operation of the Upton Reserve and to encourage the use of the Reserve and BNL for ecological research.

\section{Integration with Other Documents}

The NRMP must integrate with other requirements that govern BNL's operation. The Environmental Protection Division (EPD) is responsible for developing and implementing several management documents for BNL, including the Cultural Resource Management Plan (CRMP), Environmental Monitoring Plan, Environmental Management Systems, and the Integrated Pest Management (IPM) Assessment and Plan. Other divisions are responsible for the Standards Based Management System (SBMS), environmental restoration, infrastructure management, emergency management, and sustainability. Where requirements from various other management systems affect this plan, those requirements will be integrated by direct reference. For example, the WW I trench systems and the white pine groves are both historic features of the BNL site, but their maintenance may be, in part, within the scope of natural resource management due to the proximity of natural resources to cultural resources (i.e. forest overlaid on top of WW I trenches).

\section{Regulatory \& Policy Framework}

The development of a Natural Resource Management Plan is a contract requirement for BNL, according to DOE Order 436.1. There are also a number of federal, state, and local regulations and statutes relevant to wildlife, wetland, and natural resource management. It is BNL's policy to integrate environmental stewardship into all facets of the Laboratory's missions, to manage programs in a manner that protects the ecosystem. Some specific regulatory, secretarial, cooperative, and internal drivers are presented below.

\section{Federal Regulations}

Some Federal regulations directly or indirectly applicable to natural resource management or requiring coordination and integration include:

Endangered Species Act

Migratory Bird Treaty Act

Clean Water Act

Clean Air Act

National Historic Preservation Act

National Environmental Policy Act (NEPA) 
Comprehensive Environmental Response, Compensation and Liability Act/Superfund Amendment and

Reauthorization Act (CERCLA/SARA)

The Oil Pollution Act, Emergency Planning and Community Right to Know Act

Federal Insecticide, Fungicide and Rodenticide Act

10 CFR 1021 DOE's Rules Implementing the NEPA

10 CFR 1022 Compliance with Wetlands and Flood Plains Executive Orders

Executive Order 13423, Strengthening Greening the Government through Leadership in Federal Environmental, Energy and Transportation Management

Executive Order 13112 Invasive Species

Executive Order 13186 Responsibilities of Federal Agencies to Protect Migratory Birds

\section{State Regulations}

State regulations applicable to natural resource management include:

New York State Environmental Conservation Laws

NYS Endangered Species Act

NYS Wild, Scenic, Recreational, Rivers Act

NYS Wildlife Laws

NYS Wetlands Protections Laws

Pine Barrens Protection Act

Pine Barrens Protection Act

BNL occupies approximately five percent of the 102,000-acre Central Pine Barrens Region and works in cooperation with the Central Pine Barrens Joint Policy and Planning Commission (PBC) established by the Long Island Pine Barrens Protection Act of 1995. This Act requires preparation of a Pine Barrens Management Plan, which was completed by the PBC in 1996. Since the Act does not have its origin in a federal statute, federal facilities are not subject to it. However, BNL developed a Future Land Use Plan (BNL 1995) with considerable input from the PBC and other stakeholders. The plan does not preclude future development which may take place in pursuit of BNL's missions, but recommends that the majority of BNL's undeveloped lands be maintained as open space.

BNL participates as a member of several committees established under the Pine Barrens Protection Act, including the Central Pine Barrens Advisory Committee, Protected Lands Council (PLC), Law Enforcement Task Force, and the Wildland Fire Task Force. As a member of these committees BNL provides technical assistance and professional experience to the decision-making process of the PBC.

\section{Land Use Planning}

Since being placed on the CERCLA National Priorities List in 1989, BNL has been undergoing a comprehensive environmental cleanup. Thirty contaminated areas or facilities have been or will be remediated as part of this cleanup program (BNL 2009a). As part of BNL's responsibility for cleanup and environmental protection, Land Use and Institutional Controls (LUICS) must be implemented to prevent the exposure of workers and the public to unnecessary levels of contaminants-both chemical and radiological. This is done through administrative and engineering controls that restrict or limit access, activities, and/or use of an area.

In the future, BNL may need space for new scientific machines requiring large areas of real estate for expansion. The LUICs are taken into consideration during the planning process. The environmental aspects of development anywhere on the site are always considered during planning.

\section{Department of Energy Policies/Orders}

DOE P 141.1 Department of Energy Management of Cultural Resources

DOE P 430.1 Land and Facility Use Policy

DOE P 450.6 Secretarial Policy Statement; Environmental Safety and Health

DOE O 450.2 Integrated Safety Management 
DOE O 451.1B Chg 2 National Environmental Policy Act Compliance Program

DOE O 458.1 Admin Chg 1 Radiation Protection of the Public and Environment

\section{Laboratory Policy}

BNL has developed an Environmental Stewardship Policy that is integrated into all of the Laboratory's missions.

BNL will manage its programs in a manner that protects the ecosystem and public health. In support of this policy, BNL has made the following commitments:

- We are committed to achieving compliance with applicable environmental requirements.

- In consideration of the potential impacts of our activities on the environment, we will integrate pollution prevention/waste minimization, resource conservation, and compliance into all of our planning and decision-making. We will adopt cost-effective practices that eliminate, minimize or mitigate environmental impacts.

- We will define, prioritize, and aggressively correct and clean up existing environmental problems.

- We will work to continually improve our Environmental Management System and performance.

- We will establish appropriate environmental objectives and performance indicators to guide these efforts and measure our progress.

- We will maintain a positive, proactive, and constructive relationship with our neighbors in the community, regulators, DOE, and our other stakeholders. We will openly communicate with stakeholders on our progress and performance.

All Staff have a role in achieving the policy commitments. In addition the Laboratory Director conducts an annual review of BNL's progress on environmental goals and adherence to this policy. 


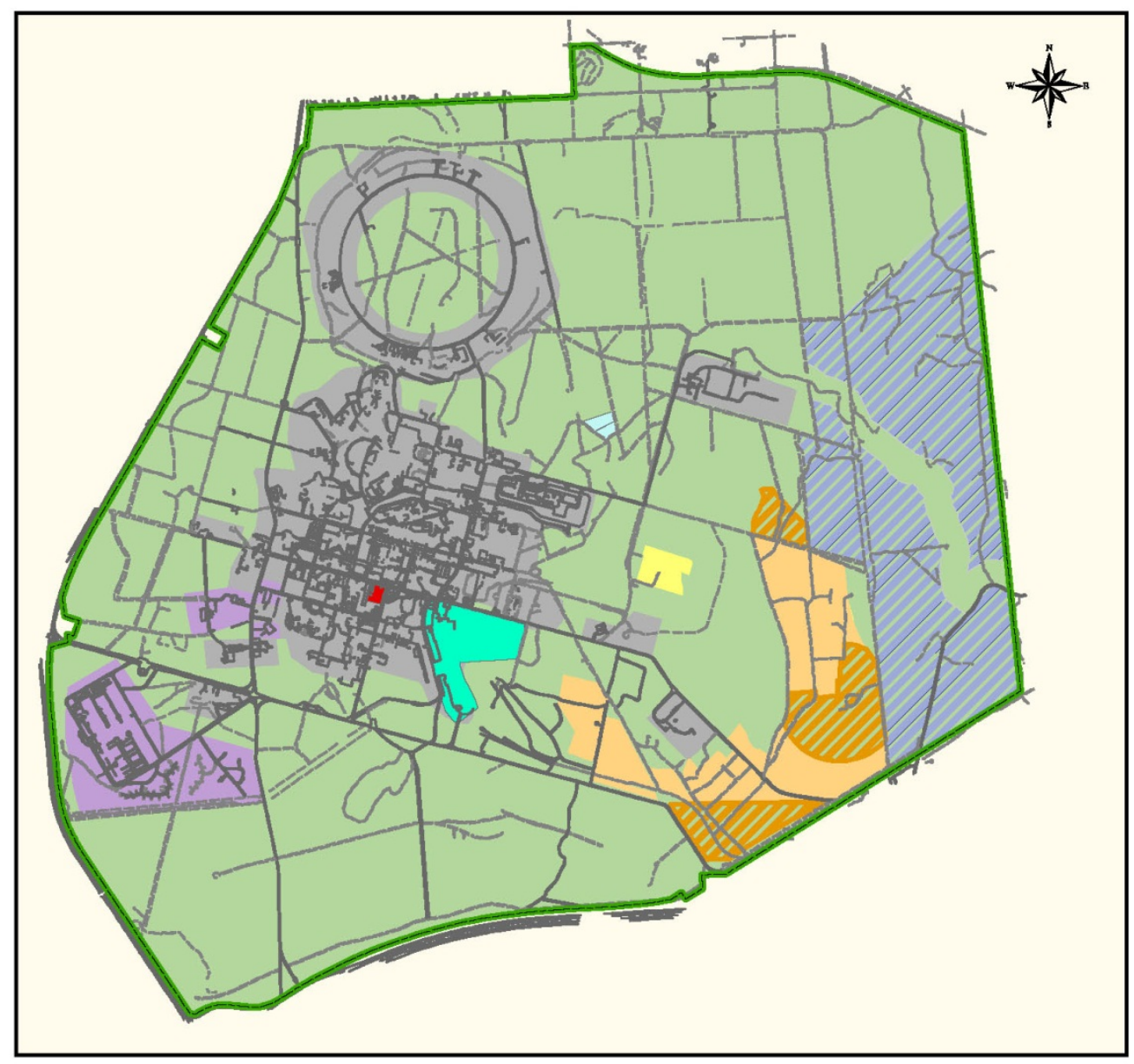

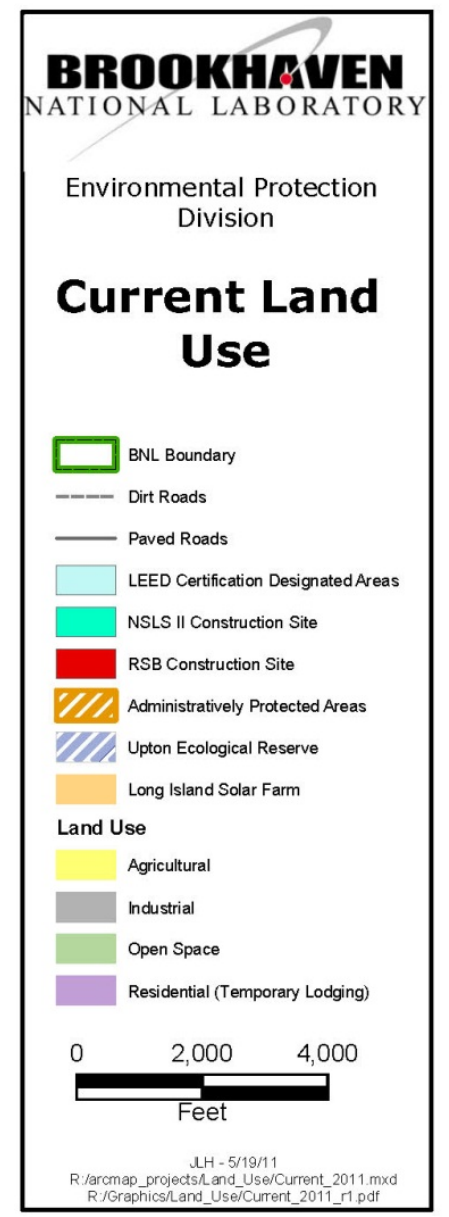

Note: This map is constantly updated. The most recent version can be found on the EPD webpage under Natural Resource Management. 


\section{Partners}

Several agencies and organizations provide technical expertise on either a cooperative or paid basis. Agencies providing cooperative and/or paid consultation support include the U.S. Department of Agriculture (USDA), Forest Service (USFS), USDA Animal Plant Health Inspection Service - Division of Wildlife Services (APHIS-WS), USDA Natural Resources Conservation Service (NRCS), U.S. National Park Service (NPS), U.S. Fish and Wildlife Service (FWS), Cornell Cooperative Extension, and New York State Department of Environmental Conservation (NYSDEC).

Cooperative efforts between BNL and the PBC provide opportunities for achieving mutual natural resource management goals. BNL lies within the Central Pine Barrens Region, the third largest protected forest area in New York State. The Commission is charged with implementing a comprehensive land use plan for the Central Pine Barrens. Two primary goals of this plan are 1) to protect, preserve, and enhance the functional integrity of the Pine Barrens ecosystem and its significant natural resources, including plant and animal populations and communities, and 2 ) to protect the quality of surface water and groundwater.

BNL is a member of several of the councils created by the PBC to foster stewardship in the Pine Barrens including the Advisory Council, the PLC, the Wildfire Task Force, and the Law Enforcement Task Force. The structure of the PLC and the expertise of its member organizations are an especially valuable resource for enhancing BNL's Natural Resource Management Program. Through BNL's continued active participation on the PLC and its cooperative interagency natural resource protection and management efforts, BNL can reap the benefits fostered by the PLC's goal "to forge stronger working relationships and partnerships between all public land holders and conservation land managers in the Central Pine Barrens so as to allow for sharing of limited resources and to strengthen the capacity of individual land managers to accomplish regional pine barrens resource protection and management goals."

Since 1996, BNL has also been one of the four organizational sponsors-along with the PBC, FERN, and the Long Island Groundwater Research Institute of State University of New York at Stony Brook-of the annual Pine Barrens Research Forum. This two-day, October event draws scientists, researchers, managers, students at all levels, teachers, agency personnel, citizens, and interested individuals together to share research initiatives and results in diverse disciplines such as ecology, surface and groundwater hydrology, wildlife, botany, fire, historical land uses, land use planning, technology, and tools.

BNL resources have also been utilized for holding the annual New York Wildfire and Incident Management Academy, PLC meetings, biennial NPS Science Symposia, and other public functions related to natural resource management.

Private organizations with expertise in wildlife and natural resource management are utilized when necessary. The Nature Conservancy (TNC) staffs a Long Island office with individuals trained and experienced in environmental conservation. This organization is utilized as a source for consultation and cooperation where applicable. Other organizations, such as the Long Island Invasive Species Management Area (LIISMA), the Long Island Native Plant Initiative (LINPI), Audubon Society, the Long Island Pine Barrens Society, and others are used where appropriate for managing or obtaining information about natural resources at BNL.

\section{Action item:}

- Maintain and improve relationships between neighboring landowners, support agencies, and private environmental groups.

- Improve management decisions through the use of innovative tools.

\section{Long Island Solar Farm (LISF)}

As part of DOE's commitment to promoting and developing renewable energy sources, DOE has entered into an agreement with BP Solar to allow the construction of a 32-megawatt (MW) photovoltaic electric generation plant on a 200-acre portion of the BNL property (Figure 1). This land was released to BP Solar by DOE under an 
easement. The solar farm will promote the use of non-polluting, renewable solar energy technology in the largestscale photovoltaic project in the Northeast (DOE 2009). As part of the NEPA process, an Environmental Assessment (EA) was written to determine the impacts of such a large scale project on the ecology and environment. Subsequently, a Finding of No Significant Impact (FONSI) was issued. Details about this project can be found in the EA.

The significance of the LISF to Natural Resources Management lies in the fact that it presents us with an opportunity to conduct a great deal of research. This is discussed in more detail in the Research section later in this document.

\section{Adaptive Management}

The Natural Resource Management program will utilize "Adaptive Management" as a mechanism for continual improvement to the program. Adaptive Management follows a similar pattern that is utilized by Integrated Safety Management and Environmental and Safety Management systems (Figure 2). It is defined below.
Adaptive management is a systematic process for continually improving management policies and practices by learning from the outcomes of operational programs. Its most effective form- "active" adaptive management-employs management programs that are designed to experimentally compare selected policies or practices, by evaluating alternative hypotheses about the system being managed. (Adaptive Management 2011).

In this plan the problems are defined through management needs; strategies are determined; actions are assigned and implemented; results are monitored, reported, and evaluated; and adjustments are made to the program.

Gaps in management are likely to be identified in the future and will need to be addressed. Significant gaps will result in the need to submit an addendum to this plan within a reasonable amount of time, while other gaps will be noted and added to the plan during major revisions.

\section{Action items:}

- Adapt natural resource management decisions based on up-to-date information gained collectively through cooperation with outside agencies and organizations.

- Write an annual summary report to chronicle the progress of current action items and add new action items as necessary.

- Update the Natural Resource Management Plan every 5 years. 
Figure 2. The Adaptive Management Process Cycle.

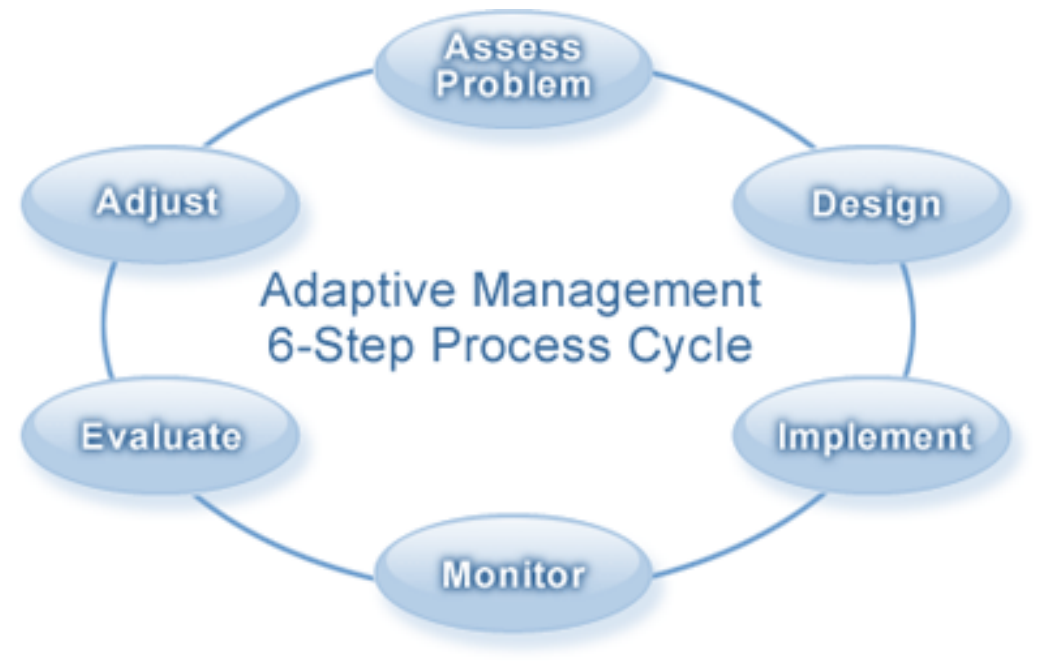

\section{Geographic Information System (GIS)}

As a part of the Natural Resource Management program, any location-based information is stored in a SQL ServerBased SDE Enterprise Geo-database by ESRI. This includes layers such as vegetation, telemetry study information, roads, buildings, invasive plant locations, cultural resources and more. Over 150 layers are available to assist in mapping and planning. As management is conducted, efforts are made to include a GIS component in all management and monitoring activities. Global Positioning System (GPS) units are available at a variety of accuracy levels to map and plot locations. Project locations and management activities are recorded for future use and analysis. Metadata (the "data about data") should also be recorded for future reference.

\section{Action item:}

- $\quad$ Continue to develop and maintain GIS layers documenting natural resources.

- Utilize these GIS layers to assist in mapping and planning.

- $\quad$ Establish metadata for all data layers and new data entries

\section{Resource Assessment}

\section{Geology and Soils}

Six major stratigraphic units that underlie most of Long Island have been identified in test drilling on site (BNL 1977). From the deepest level to the surface, these units include: the Pre-Cretaceous bedrock, the Raritan formation (with two members), the Magothy formation, the Gardiners clay, and the upper Pleistocene deposits. The upper Pleistocene deposits consist primarily of glacial sand and gravel, plus associated local silt and clay. This unit represents the outwash and moraine deposits of the Wisconsin period. At BNL the thickness of the highly permeable upper Pleistocene deposits varies between 120 and 250 feet (BNL 2002). The sandiest soil is found on the eastern third of the island. On the south shore coastal plain, soils are typically moister. On the north shore the soil is typically finer than elsewhere on the island. In general, the soils at BNL are typical of pine barrens ecosystems. They are quick-draining, consisting of $80-96 \%$ sand, low in organic matter, nutrient-poor and high in acidity.

\section{Vegetation Types}

BNL is located in the heart of the Central Pine Barrens. The Central Pine Barrens Region of Long Island represents one of only three known pine barrens ecosystems in the world. Approximately 3,450 acres of the BNL consists of pine barrens habitat. This acreage has been adjusted to reflect the clearing of approximately 165 acres of pine barrens for the placement of solar panels for the Long Island Solar Farm Project. The pine barrens consists 
primarily of communities of pitch pine (Pinus rigida) and oak species (Quercus coccinea, Q. rubra, Q. alba, Q. velutina) with an understory of scrub oak ( $Q$. ilicifolia) and a variety of ericaceous (heath) shrubs like huckleberry (Gaylussacia baccata), blueberry species (Vaccinium spp.), bearberry (Arctostaphylos uva-ursi), and wintergreen (Gaultheria procumbens) (FWS 1997). Other common species include bracken fern (Pteridium aquilinum), little bluestem (Schizachyrium scoparium), and Pennsylvania sedge (Carex pensylvanica).

Based on data collected for the creation of a map of vegetation assemblages on site there are three main forest types at BNL (Figure 3). These are pitch pine/white oak (Q. alba) forest consisting of approximately 1,200 acres, scarlet oak $(Q$, coccinea)-heath forest consisting of approximately 1,000 acres, and pitch pine/mixed oak-heath forest consisting of a little over 900 acres. In 1934, the Civilian Conservation Corps (CCC) established the Upton National Forest and several CCC camps began planting trees on the former Army site. This is the origination of the white pine (Pinus strobus) forest on site that currently covers over 440 acres and is considered a cultural resource as well as a natural one that must be managed. These acreage values have also been adjusted to reflect the habitat lost to the Long Island Solar Farm project.

Other existing vegetation assemblages include red maple (Acer rubrum)/scarlet oak-mesic heath forest; red maplemesic heath forest; red maple-black gum (Nyssa sylvatica) wet forest; and black cherry (Prunus serotina) forest. In addition, approximately 220 acres are classified as early successional consisting of an array of grasses that were either planted or colonized on their own. These include little bluestem and Indian grass (Sorghastrum nutans), big bluestem (Andropogon gerardii), broom sedge (Andropogon virginicus), and a few species of panic grass (Panicum spp.). A variety of heath species as well as species of moss and lichen can be found in these areas. Cryptobiotic soils may also be present in some of these areas.

\section{Wetlands and the Peconic River}

BNL has about 200 acres of wetlands on-site. These include six jurisdictional wetlands and numerous small basins and ponds that provide a variety of habitats (Figure 4). The Peconic River and Zeke's Pond are both Class I wetlands under NYSDEC regulations. The east central part of the Laboratory contains wetlands that have been historically ditched for mosquito control. This area is likely no longer a fully functional wetland.

The headwaters of the Peconic River begin near the Laboratory west of the William Floyd Parkway and flow through it from west to east. The river near the headwaters is very narrow, slow-moving and heavily vegetated with species like leatherleaf (Chamaedaphne calyculata), round-leaf sundew (Drosera rotundifolia), and several species of peat moss (Sphagnum spp.) (FWS 1997). The marshes in this area also contain species such as blue manna-grass (Glyceria obtusa), tussock sedge (Carex stricta), bluejoint grass (Calamagrostis canadensis), as well as swamp loosestrife (Decodon verticillatus) and red maple.

Vernal pools and shallow coastal plain ponds are common in the area of the headwaters. Coastal plain ponds are globally significant habitats characterized by gently sloping shorelines and because they are groundwater-fed, water levels fluctuate seasonally and yearly based on the height of the water table (FWS 1997). These fluctuating water levels are essential to the survival of the rare pondshore vegetation communities. Times of high water will kill the saplings of woody species that invade from the surrounding area and times of low water allow for the germination of seeds and growth of new plants. Coastal plain ponds are home to a variety of carnivorous plants like bladderworts (Utricularia spp.) and sundews (Drosera spp.) as well as numerous rush species (Juncus spp.) (New York Natural Heritage Program 2011). 
Figure 3. Map of vegetation assemblages at BNL.

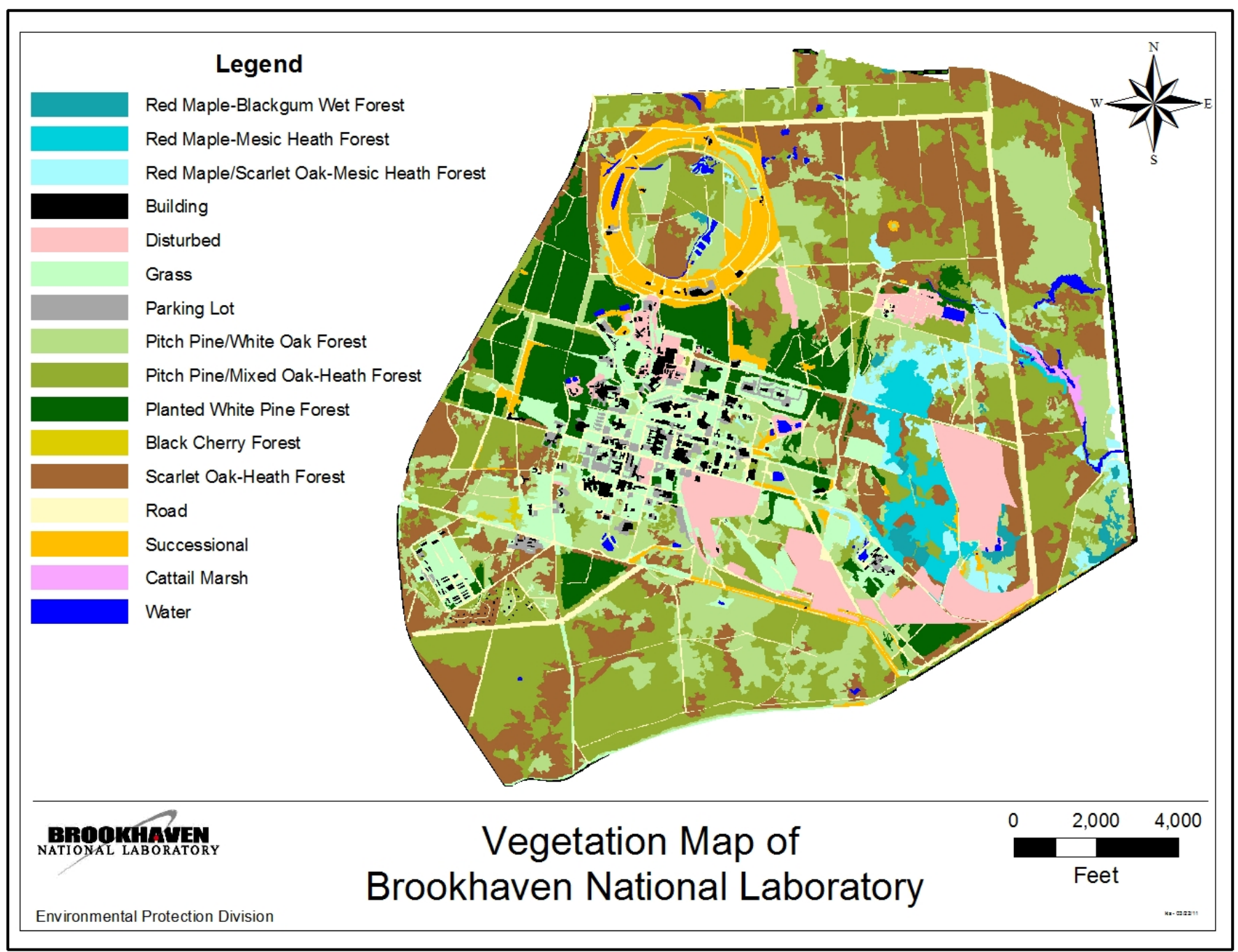


Figure 4. Locations of wetlands at BNL.

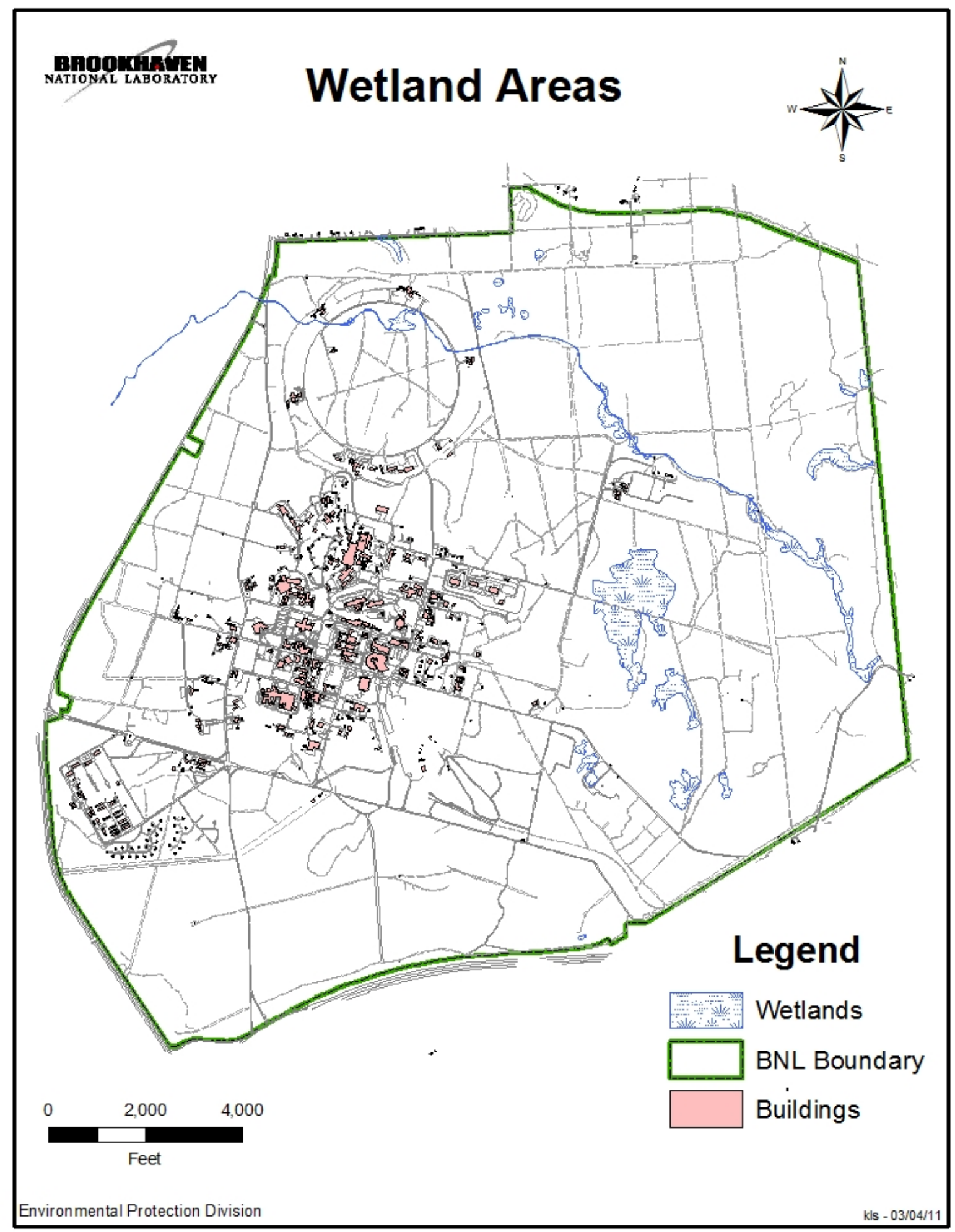




\section{Fire Ecology}

Pine barrens have evolved over hundreds to thousands of years in the presence of frequent fires. As a result, plant and animal species of the pine barrens have become adapted to conditions created by periodic fires. For example, pitch pine seeds germinate and grow best on mineral soil in full sunlight, conditions created when fire burns off surface litter and competing vegetation (BNL 2009b).

As the pine barrens are found on well drained sandy soils with low nutrients and high acidity, many of the plants in the pine barrens produce waxes, resins, or volatile compounds in their leaves to help retain moisture. These substances tend to be highly flammable. Additional plant characteristics that favor fire include decay-resistant litter of low water-absorbing capacity that accumulates on the soil surface, and abundant dead branches and twigs. Pitch pines are able to survive most fires due to thick, insulating bark and to their unusual ability to rapidly sprout from buds in the trunk and root collar. Shrubs and herbs in the pine barrens also rapidly sprout from underground roots and rhizomes (BNL 2009b).

Some research asserts that pine barrens species alter their environment to favor their own perpetuation (Noble and Slatyer 1977, Rowe 1983). Fire-tolerant species promote ignition with their volatile foliage. Fire then consumes the available litter that would otherwise decompose and enrich the soil making it more hospitable for less fire-tolerant species. Reduced nutrient levels favor species that tolerate fire and poor soil, and the presence of these species favors recurring fire. This feedback loop may be destabilized when fires are suppressed or prevented, when nutrients are added to the soil, or by prolonged wet weather. With prolonged fire exclusion (through active wildfire suppression and fire prevention efforts), plant succession ultimately could result in the replacement of pine barrens with oak forests.

At BNL, fire has been aggressively suppressed for at least 75 years and as a result there has been a large buildup of fuels in the forest understory in the form of leaf litter and branches. This fuel buildup could ultimately lead to the ignition of a catastrophic wildfire which would not only adversely impact the existing ecology, but potentially endanger structures and human life. Further information can be found in the Fire Management Plan (BNL 2009b).

\section{Special Status Species}

BNL is home to a number of plants and animals that are considered special status species including the New York State endangered tiger salamander (Ambystoma tigrinum tigrinum) and Persius duskywing (Erynnis persius persius), and the state threatened banded sunfish (Enniacanthus obesus), swamp darter (Etheostoma fusiforme), frosted elfin butterfly (Callophrys iris) little bluet (Enallagma minisculuml), pine barrens bluet (Enallagma recurvatum) and northern harrier (Circus cyaneus). Endangered and threatened plants include the crested fringed orchid (Plantathera cristata), stargrass (Aletris farinosa), and stiff goldenrod (Solidago rigida). In addition, there are a number of species considered as part of NYSDEC's New York Comprehensive Wildlife Conservation Strategy to be "species of greatest conservation need" (SGCN). This designation has no legislative mandate. It is intended to create an awareness of species which are declining, but may not yet have a special status in the hopes that management of those species now will prevent the need that they be listed in the future. Table 1 contains a list of all special status species either confirmed to be present on site or likely to be present on site.

\section{Action item:}

- Maintain and update the list of special status species.

- Identify habitats of special status species as necessary.

- Continue surveys of Odonates, reptiles and amphibians. 
Table 1. New York State special status species at BNL.

\begin{tabular}{|c|c|c|c|}
\hline \multicolumn{4}{|c|}{$\begin{array}{c}\text { New York State Threatened \& Endangered Species, Species of Special Concern, \& Species of Greatest } \\
\text { Conservation Need }\end{array}$} \\
\hline Common Name & Scientific Name & State Status & BNL Status \\
\hline \multicolumn{4}{|l|}{ Insects } \\
\hline Comet darner & Anax longipes & SGCN & Confirmed \\
\hline Frosted elfin & Callophrys iris & $\mathrm{T}$ & Likely \\
\hline New England bluet & Enallagma laterale & SGCN & Likely \\
\hline Little bluet & Enallagma minusculum & $\mathrm{T}$ & Confirmed \\
\hline Scarlet bluet & Enallagma pictum & $\mathrm{T}$ & Likely \\
\hline Pine Barrens bluet & Enallagma recurvatum & $\mathrm{T}$ & Confirmed \\
\hline Mottled duskywing & Erynnis martialis & SC & Likely \\
\hline Persius duskywing & Erynnis persius persius & $\mathrm{E}$ & Likely \\
\hline \multicolumn{4}{|l|}{ Fish } \\
\hline Banded sunfish & Enniacanthus obesus & $T$ & Confirmed \\
\hline Swamp darter & Etheostoma fusiforme & $\mathrm{T}$ & Confirmed \\
\hline \multicolumn{4}{|l|}{ Amphibians } \\
\hline Marbled salamander & Ambystoma opacum & SC & Confirmed \\
\hline Eastern tiger salamander & Ambystoma tigrinum tigrinum & $\mathrm{E}$ & Confirmed \\
\hline Fowler's toad & Bufo fowleri & SGCN & Confirmed \\
\hline Four-toed salamander & Hemidactylium scutatum & SGCN & Confirmed \\
\hline Eastern spadefoot toad & Scaphiopus holbrookii & SC & Confirmed \\
\hline \multicolumn{4}{|l|}{ Reptiles } \\
\hline Worm snake & Carphophis amoenus & SC & Confirmed \\
\hline Snapping turtle & Chelydra serpentina & SGCN & Confirmed \\
\hline Spotted turtle & Clemmys guttata & SC & Confirmed \\
\hline Northern black racer & Coluber constrictor & SGCN & Confirmed \\
\hline Eastern hognose snake & Heterodon platyrhinos & SC & Confirmed \\
\hline Stinkpot turtle & Sternotherus odoratus & SGCN & Confirmed \\
\hline Eastern box turtle & Terrapene carolina & SC & Confirmed \\
\hline Eastern ribbon snake & Thamnophis sauritus & SGCN & Confirmed \\
\hline \multicolumn{4}{|c|}{ Birds (nesting, transient, or potentially present) } \\
\hline Cooper's hawk & Accipiter cooperii & SC & Confirmed \\
\hline Sharp-shinned hawk & Accipiter striatus & SC & Confirmed \\
\hline Grasshopper sparrow & Ammodramus savannarum & SC & Confirmed \\
\hline Great egret & Ardea alba & SGCN & Confirmed \\
\hline Whip-poor-will & Caprimulgus vociferus & SC & Likely \\
\hline Northern harrier & Circus cyaneus & $\mathrm{T}$ & Confirmed \\
\hline Black-billed cuckoo & Coccyzus erythropthalmus & SGCN & Confirmed \\
\hline Northern bobwhite & Colinus virginianus & SGCN & Confirmed \\
\hline Prairie warbler & Dendroica discolor & SGCN & Confirmed \\
\hline Horned lark & Eremophila alpestris & SC & Confirmed \\
\hline Wood thrush & Hylocichla mustelina & SGCN & Confirmed \\
\hline Red-headed woodpecker & Melanerpes erythrocephalus & SC & Confirmed \\
\hline Osprey & Pandion haliaetus & SC & Confirmed \\
\hline Scarlet tanager & Piranga olivacea & SGCN & Confirmed \\
\hline Glossy ibis & Plegadis falcinellus & SGCN & Confirmed \\
\hline Brown thrasher & Toxostoma rufum & SGCN & Confirmed \\
\hline Blue-winged warbler & Vermivora pinus & SGCN & Confirmed \\
\hline \multicolumn{4}{|l|}{ Plants } \\
\hline Stargrass & Aletris farinosa & $T$ & Confirmed \\
\hline Butterfly weed & Asclepias tuberosa & V & Confirmed \\
\hline
\end{tabular}




\begin{tabular}{|c|c|c|c|}
\hline $\begin{array}{l}\text { Spotted wintergreen } \\
\text { Flowering dogwood }\end{array}$ & $\begin{array}{l}\text { Chimaphila maculata } \\
\text { Cornus florida }\end{array}$ & $\begin{array}{l}\mathrm{V} \\
\mathrm{V}\end{array}$ & $\begin{array}{l}\text { Confirmed } \\
\text { Confirmed } \\
\end{array}$ \\
\hline Common Name & Scientific Name & State Status & BNL Status \\
\hline Pink lady's slipper & Cypripedium acaule & V & Confirmed \\
\hline Winterberry & Ilex verticillata & V & Confirmed \\
\hline Sheep laurel & Kalmia angustifolia & V & Confirmed \\
\hline Narrow-leafed bush clover & Lespedeza augustifolia & $\mathrm{R}$ & Confirmed \\
\hline Ground pine & Lycopodium obscurum & V & Confirmed \\
\hline Bayberry & Myrica pensylvanica & V & Confirmed \\
\hline Cinnamon fern & Osmunda cinnamomera & V & Confirmed \\
\hline Clayton's fern & Osmunda claytoniana & V & Confirmed \\
\hline Royal fern & Osmunda regalis & V & Confirmed \\
\hline Crested fringed orchid & Plantathera cristata & $E$ & Likely \\
\hline Swamp azalea & Rhododendron viscosum & V & Confirmed \\
\hline Long-beaked bald-rush & Rhynchospora scirpoides & $\mathrm{R}$ & Confirmed \\
\hline Stiff goldenrod & Solidago rigida & $\mathrm{T}$ & Confirmed \\
\hline New York fern & Thelypteris novaboracensis & V & Confirmed \\
\hline Marsh fern & Thelypteris palustris & V & Confirmed \\
\hline Virginia chain-fern & Woodwardia virginica & $\mathrm{V}$ & Confirmed \\
\hline \multicolumn{4}{|c|}{ Notes: * information based on 6 NYCRR Part 182, 6 NYCRR Part 193, and BNL survey data. } \\
\hline \multicolumn{4}{|c|}{ No federally listed threatened or endangered species are known to occur at BNL. } \\
\hline \multicolumn{4}{|c|}{$\begin{array}{l}\mathrm{E}=\text { endangered, } \mathrm{T}=\text { threatened, } \mathrm{SC}=\text { species of special concern, } \mathrm{R}=\text { rare, } \mathrm{V}=\text { exploitably vulnerable, } \mathrm{SGCN}=\text { species of } \\
\text { greatest conservation need }\end{array}$} \\
\hline
\end{tabular}

\section{Migratory Birds}

Songbird surveys have been conducted annually from April - September at BNL since the year 2000. Monitoring involves recording ambient weather conditions at the beginning and end of each of the seven routes, and counting the number of individuals of each species heard or seen during a five minute period at each point on the route. Points are spaced approximately 300 meters apart to prevent overlap of counts from point to point. To date, 116 species of birds have been detected at BNL. See 
Table 2 for a list of species documented on site.

Routes next to wetlands (Peconic River, Biology Fields, and Z-path routes) continue to have the highest number of species detected. This is likely due to higher biodiversity in these habitats that support a greater variety of nesting sites and foraging opportunities. Results along the Z-Path route are also beginning to indicate high number of species, likely due to the variability of habitats along this route. The Z-Path route goes through the most diverse habitats, ranging from pine forest, to wetlands, to mixed forest. 
Table 2. Bird species documented on site.

\begin{tabular}{|c|c|c|c|}
\hline Common Name & Scientific Name & Common Name & Scientific Name \\
\hline Acadian Flycatcher & Empidonax virescens & Hairy Woodpecker & Picoides villosus \\
\hline American Crow & Corvus brachyrhynchos & Hermit Thrush & Catharus guttatus \\
\hline American Kestrel & Falco sparverius & Herring Gull & Larus argentatus \\
\hline American Redstart & Setophaga ruticilla & Horned Lark & Eremophila alpestris \\
\hline American Robin & Turdus migratorius & House Finch & Carpodacus mexicanus \\
\hline Baltimore Oriole & Icterus galbula & House Wren & Troglodytes aedon \\
\hline Barn Swallow & Hirundo rustica & Indigo Bunting & Passerina cyanea \\
\hline Belted Kingfisher & Ceryle torquata & Killdeer & Charadrius vociferus \\
\hline Bewick's Wren & Thryomanes bewickii & Magnolia Warbler & Dendroica magnolia \\
\hline Black-and-White Warbler & Mniotilta varia & Mallard Duck & Anas platyrhyncos \\
\hline Black-billed Cuckoo & Coccyzus erythropthalmus & Merlin & Falco columbarius \\
\hline Black-capped Chickadee & Poecile atricapillus & Mourning Dove & Zenaida macroura \\
\hline Blackpole & Dendroica striata & Nashville Warbler & Vermivora ruficapilla \\
\hline $\begin{array}{l}\text { Black-throated Green } \\
\text { Warbler }\end{array}$ & Dendroica virens & Northern Bobwhite & Colinus virginianus \\
\hline Blue Jay & Cyannocitta cristata & Northern Cardinal & Cardinalis cardinalis \\
\hline Blue-Grey Gnatcatcher & Polioptila caerulea & Northern Flicker & Colaptes auratus \\
\hline Blue-headed Vireo & Vireo solitarius & Northern Mockingbird & Mimus polyglottos \\
\hline Blue-winged Warbler & Vermivora pinus & Northern Parula & Parula americana \\
\hline Broad-winged Hawk & Buteo platyteris & $\begin{array}{l}\text { Northern Rough-winged } \\
\text { Swallow }\end{array}$ & Steligdopteryx serripennis \\
\hline Brown Creeper & Certhia americana & Orchard Oriole & Icterus spurius \\
\hline Brown Thrasher & Toxostoma rufum & Osprey & Pandion haliaetus \\
\hline Brown-headed Cowbird & Molothrus ater & Ovenbird & Seiurus aurocapillus \\
\hline Canada Goose & Branta canadensis & Palm Warbler & Dendroica palmarum \\
\hline Carolina Wren & Thryothorus ludovicianus & Pine Warbler & Dendroica pinus \\
\hline Cedar Waxwing & Bombycilla cedrorum & Plain Pigeon & Columbus livia \\
\hline Chestnut-sided Warbler & Dendroica pensy/vanica & Prairie Warbler & Dendroica discolor \\
\hline Chimney Swift & Chaetura pelagica & Purple Martin & Progne subis \\
\hline Chipping Sparrow & Spizella passerina & Red-bellied Woodpecker & Melanerpes carolinus \\
\hline Common Grackle & Quiscalus quiscula & Red-breasted Nuthatch & Sitta canadensis \\
\hline Common Loon & Gavia immer & Red-eyed Vireo & Vireo olivaceus \\
\hline Common Peafowl & Pavo cristatus & Red-headed Woodpecker & $\begin{array}{l}\text { Melanerpes } \\
\text { erythrocephalas }\end{array}$ \\
\hline Common Yellowthroat & Geothlypis trichas & Red-tailed Hawk & Buteo jamaicensis \\
\hline Cooper's Hawk & Accipiter cooperii & Red-throated Loon & Gavia stellata \\
\hline Dark-eyed Junco & Junco hyemalis & Red-winged Blackbird & Agelaius phoeniceus \\
\hline Double-crested Cormorant & Phalacrocorax auritus & Ring-billed Gull & Larus delawarensis \\
\hline Downy Woodpecker & Picoides pubescens & Rose-breasted Grossbeak & Pheucticus ludovicianus \\
\hline Eastern Bluebird & Sialia sialis & Ruby-crowned Kinglet & Regulus calendula \\
\hline Eastern Kingbird & Tyranus tyranus & $\begin{array}{l}\text { Ruby-throated } \\
\text { Hummingbird }\end{array}$ & Archilochus colubris \\
\hline
\end{tabular}




\begin{tabular}{|c|c|c|c|}
\hline Eastern Phoebe & Sayornis phoebe & Savannah Sparrow & Passerculus sandwichensis \\
\hline Eastern Screech Owl & Otus asio & Scarlet Tanager & Piranga olivacea \\
\hline Common Name & Scientific Name & Common Name & Scientific Name \\
\hline Eastern Towhee & Pipilo erythrophthalmus & Sharp-shinned Hawk & Accipiter striatus \\
\hline Eastern Wood Peewee & Contopus virens & Song Sparrow & Melospiza melodia \\
\hline European Starlings & Sturnus vulgaris & Summer Tanager & Piranga rubra \\
\hline Field Sparrow & Spizella pusilla & Tree Swallow & Tachycineta bicolor \\
\hline Fox Sparrow & Passerella iliaca & Tufted Titmouse & Baeolophus bicolor \\
\hline Fish Crow & Corvus ossifragus & Veery & Catharus fuscescens \\
\hline Glossy Ibis & Plegadis falcinellus & White-breasted Nuthatch & Sitta carolinensis \\
\hline Golden Eagle & Aquila chrysaetos & White-eyed Vireo & Vireo griseus \\
\hline Golden-crowned Kinglet & Regulus satrapa & White-throated Sparrow & Zonotrichia albicollis \\
\hline Goldfinch & Carduelis tristis & Wild Turkey & Meleagris gallopavo \\
\hline Grasshopper Sparrow & $\begin{array}{l}\text { Ammodramus } \\
\text { savannarum }\end{array}$ & Wood Duck & Aix sponsa \\
\hline Great Black-backed Gull & Larus marinus & Wood Thrush & Hylocichla mustelina \\
\hline Great Blue Heron & Ardea herodias & Worm-eating Warbler & Helmitheros vermivorus \\
\hline Great Crested Flycathcer & Myiarchus crinitus & Yellow Warbler & Dendroica petechia \\
\hline Great Egret & Ardea alba & Yellow-bellied Sapsucker & Sphyrapicus varius \\
\hline Great Horned Owl & Bubo virginianus & Yellow-billed Cuckoo & Coccyzus americanus \\
\hline Green Heron & Butorides virescens & Yellow-rumped Warbler & Dendroica coronata \\
\hline Grey Catbird & Dumetella carolinensis & Yellow-throated Warbler & Dendroica dominica \\
\hline
\end{tabular}

\section{Other Species}

\section{Wild Turkey}

The eastern wild turkey (Meleagris gallapavo) was re-introduced to Long Island in 1992 by NYSDEC. The original introduction occurred in two locations, the Montauk Peninsula, and at Southaven County Park southwest of BNL. The Southaven population quickly migrated down the Carmans River to Wertheim National Wildlife Refuge and up the Carmans River and across William Floyd Parkway to BNL. The population of wild turkey was first estimated at 175 birds in 1999, with steady growth occurring through to around 2005. Habitat at BNL supports the continued existence of the wild turkey. The primarily oak-dominated woodlands provide adequate food source in both summer (insects) and winter (acorns and other seeds) in most years, while stands of white pines provide insulating shelter in colder months. The current estimated population is between 300 and 500 birds, dependent upon mast crops.

\section{Canada Geese}

Canada geese (Branta canadensis) have established non-migratory populations throughout the Midwest and northeastern United States. Currently, a relatively small population (approximately 80-85 birds) is established at BNL. Resident Canada geese at BNL typically feed on lawn grasses and nest in areas next to buildings, along drainage swales, recharge basins, and the Sewage Treatment Plant (STP).

\section{White-tailed Deer}

White-tailed deer (Odocoileus virginianus) are the most prevalent large mammal species on Long Island and at BNL. In 1966, the population was estimated at approximately 267 animals. A study in 1992 determined that BNL had a population of approximately 700 animals (85/sq. mi). Follow-up surveys in December 2000 estimated 1,942 animals (236/ sq. mi). Deer surveys have been conducted semi-annually since then using a modified distance sampling technique with transects and aerial fly-overs. Transects are driven throughout the property and a 
modified distance-based approach is applied. A GIS-based population model has been created to produce an estimate based on vegetation types.

Population levels are considered to be above the ecosystems carrying capacity and the effects of overpopulation on the ecosystem are still evident. Most scientific literature suggests a population of deer should be between 10 and 30 animals per square mile. This would be equivalent to the population levels seen in 1966.

High deer populations have resulted in virtually every ornamental shrub being grazed within 4 to 5 feet of the ground. Browse lines on trees and in the forest are evident, and the forest has a lack of seedlings and, in most areas, saplings that are needed for continued forest regeneration. Decreased food supplies together with overpopulation have resulted in most deer at BNL being malnourished; this has led to an increased death rate in deer.

Invasive Species

Executive Order 13112, entitled Invasive Species, states that governmental agencies will have in-place mechanisms for identifying invasive species and for the early detection, control, and removal of invasive species when it is practical to do so. During the summers of 2003 and 2005 interns surveyed and mapped invasive plant species at BNL. 
Table 3 contains a list of the species found and the number of infestations found of each species. From these data an Invasive Species Prevention Zone (ISPZ) was delineated that includes approximately 2,400 acres (Figure 5). The ISPZ has been broken into two units and spans the southern, eastern, and northern portions of the Laboratory. Unit I is approximately 810 acres and encompasses the southern section of the Laboratory from Princeton Ave. to the Long Island Expressway with the exception of the apartment and cottage area. Unit II is 1,586 acres and includes the Upton Reserve, the area north of Fifth Ave and east of the Stump Dump, and the area east of the RHIC to the East Firebreak. These areas were chosen due to the large expanses of undeveloped land and minimal invasive species already present. The ISPZ also contains many environmentally sensitive wetlands and ponds. Unit II also buffers the Robert Cushman County Park. An ISPZ plan was written and should be referenced for information on the locations of infestations and plans for management (BNL 2008).

In addition, BNL has been an active member of LIISMA since its inception in 2001 and participates on the Scientific Review Committee-a LIISMA subcommittee tasked with the scientific assessment of the invasiveness of plant species on both Long Island and New York State as a whole. This committee, in turn, informs the respective Invasive Species Advisory Councils for Nassau and Suffolk Counties and recommends new species to be added to the existing "Do Not Sell" lists.

Few non-native pest and pathogen species currently threaten the natural resources of BNL. European gypsy moth (Lymantria dispar) has been present on Long Island for many decades and though infestations periodically impact the oak species in the Pine Barrens (often in combination with native defoliators), their populations have been reduced by the presence of a fungus (Entomophaga maimaiga) that has been released on more than one occasion as a biological control agent.

Sirex woodwasp (Sirex noctilio) is not currently present on Long Island, but has been documented in 15 counties in upstate New York. This species is a potentially serious threat to both the pitch pine and eastern white pine trees at BNL. It has decimated pine plantations in many parts of the southern hemisphere and has no known native controls. While the female wasp is laying her eggs in the bark of a susceptible tree, she injects a toxic mucous and a fungus into the tree. The mucous kills the wood from the egg-laying site on upward and the fungus then feeds on the dead wood. The larvae, in turn, feed on the fungus and bore deep into and through the wood. This makes the wasp extremely difficult to detect and control. While it prefers non-native pine species like Scots pine, it will attack any native softwood species. 
Table 3. List of invasive species found within the ISPZ.

\begin{tabular}{|l|l|c|}
\hline \hline \multicolumn{2}{|c|}{ Scientific Name } & Nommon Name \\
\hline \hline Acer platanoides & Norway maple & 1 \\
\hline Artemisia vulgaris & Mugwort & 3 \\
\hline Berberis thunbergii & Japanese barberry & 114 \\
\hline Carduus nutans & Musk thistle or nodding thistle & 1 \\
\hline Celastrus orbiculatus & Oriental bittersweet & 6 \\
\hline Centaurea maculosa & Spotted knapweed & 1 \\
\hline Eleagnus umbellata & Autumn olive & 1 \\
\hline Lonicera japonica & Japanese honeysuckle & 2 \\
\hline Phragmites australis & Common reed & 53 \\
\hline Robinia pseudoacacia & Black locust & 20 \\
\hline Rosa multiflora & Muliflora rose & 2 \\
\hline Solanum dulcamara & Climbing nightshade & 1 \\
\hline Cynanchum louiseae & Black swallow-wort & 2 \\
\hline
\end{tabular}

\section{Feral and Nuisance Animals}

Feral and nuisance animals have the potential to cause problems that could impact worker health, cause property damage, or affect biodiversity. Feral and free-ranging animals (domestic cats and dogs) have the potential to carry diseases (rabies, distemper, toxoplasmosis, etc.) that are transmissible to humans and native fauna, to cause unpleasant odors from urine and feces, and to affect biodiversity by altering predation patterns for birds, reptiles, amphibians, and small mammals. Nuisance situations are defined as being unwanted human-animal interactions and include such situations as rodents chewing cables, animals in food preparation areas and garbage collection areas, animals under portable buildings (e.g. groundhogs, skunks, raccoons, etc.), and deer destroying vegetation. Migratory birds can also pose a problem. For example, killdeer have made their nests on construction sites and barn swallows have built nests in buildings slated for demolition.

\section{Cultural Resources}

In 2003 the Laboratory developed a Cultural Resource Management Plan to better manage cultural resources identified on site. To date, the Cultural Resource Program has identified several culturally significant areas that may be affected by natural resource activities. There is a potential that prehistoric features and artifacts may exist in some habitats. Prior to BNL, the property was part of Camp Upton during World War I and II. As a result, a number of historic elements still exist on the site. WW I trenches and foundations can be found in some of the forested areas as well as unexploded ordnance and military artifacts. An archeological survey has also revealed the remains of two homes from the 1800's. Actions such as prescribed fire, fire suppression, and forest thinning (the white pines) may significantly impact historic features and artifacts if care is not taken during the planning phase, therefore, it is important that knowledge of cultural resources be fully integrated into natural resource planning. Cultural Resource Management issues are now routinely incorporated in natural resource planning.

\section{Action item:}

- Continue to develop and maintain GIS layers documenting the location of cultural resources. The Natural Resource Manager will identify cultural resources that could be affected by natural resource activities. Pre- and post-surveys for cultural resources will be performed in prescribed fire areas. 
Figure 5. Location of ISPZs at BNL.

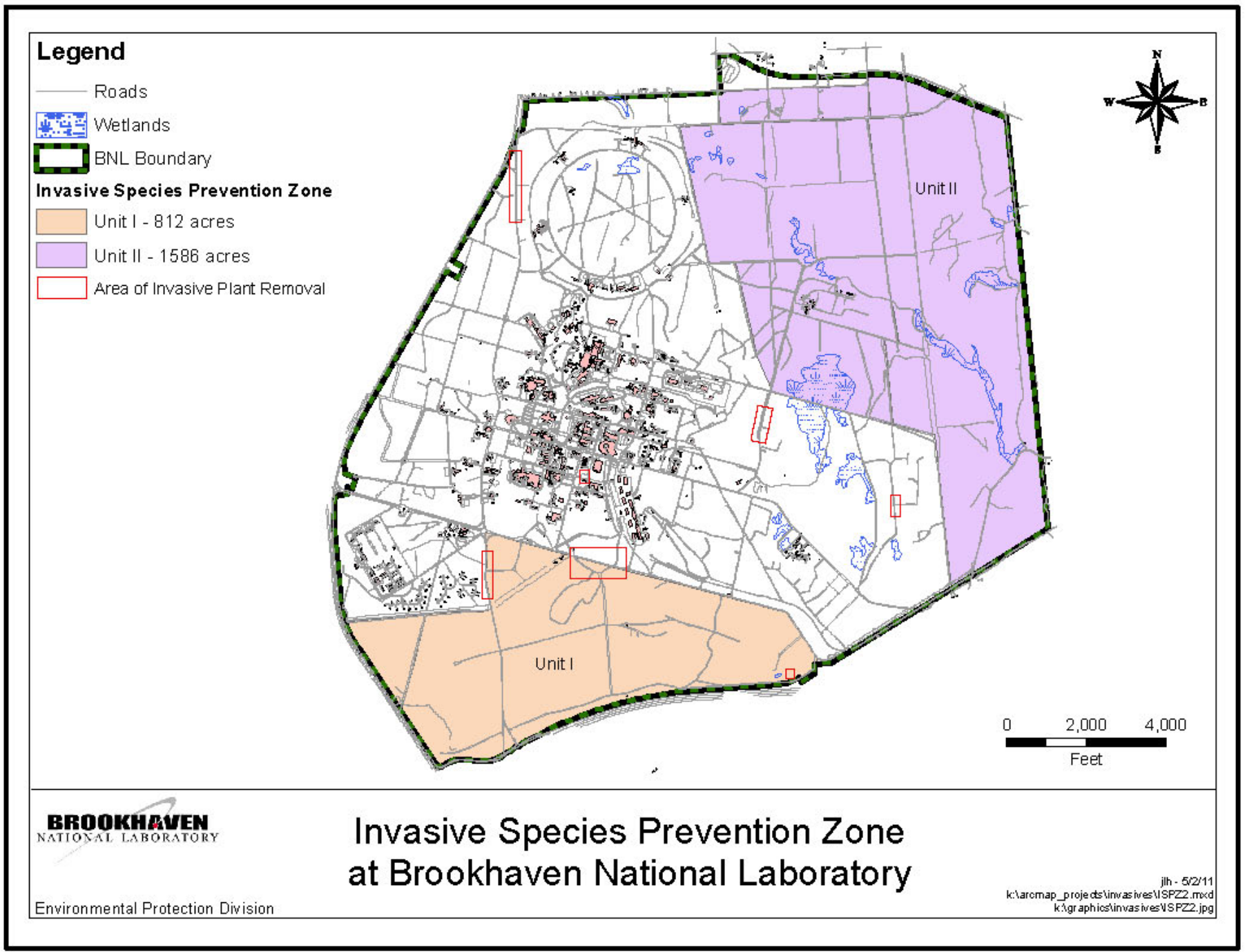




\section{Monitoring \& Management Recommendations}

\section{Habitat Monitoring \& Management}

\section{Freshwater Wetland Monitoring}

In order to understand the status of the freshwater wetlands of the Long Island Pine Barrens, FERN developed a monitoring protocol to collect data to measure indicators associated with several primary ecological attributes of wetlands. By collecting and analyzing the data on the current conditions of the freshwater wetlands of the Pine Barrens, the monitoring program would provide baseline wetland health data to enable detecting future change due to threats or management and conservation efforts. It will also help to identify research needs within the Long Island Pine Barrens. This protocol uses a combination of bio-assemblage monitoring methods. Physical features are described, including the presence or absence of buffer zones and effects of human impacts. Water and sediment quality is characterized and lists of plant species are compiled. Measures of soil compaction may document effects of all-terrain vehicles (ATVs) and other recreational activities. Odonates inhabiting the wetlands are identified and documented. New York designated SGCN and invasive species are recorded as well (FERN 2008). Little information currently exists about the state of wetlands in the Pine Barrens region which is unfortunate as wetlands provide many essential functions and support a great deal of wildlife.

Action item:

- Determine functionality of BNL central wetlands.

- Explore implementation of these protocols at BNL.

- Maintain or improve wetland functions.

Peconic River Flow Monitoring

Peconic River flow is measured at several locations including above the outfall (HE), down river at the East Firebreak ( $\mathrm{HMn})$, and near the boundary of the Laboratory (HQ). In addition, flows from the central wetlands are monitored before they enter the Peconic River station at the East Firebreak (HMs), and flows from the STP are measured prior to discharge into the Peconic River. With changes in regulatory limits for metals in BNL's discharge to surface water, BNL is expecting to discontinue STP discharge to the Peconic River in favor of discharging directly to groundwater. Should BNL move to a groundwater discharge system the need for flow monitoring will be completed and the potential for removing monitoring stations will also be evaluated. Removal or modification of the monitoring stations would improve fish migratory access during high flows.

\section{Operable Unit (OU) V Peconic River Remediation Program}

The Peconic River clean up began in April 2004 and concluded in May 2005. Flows from the upstream portion of the river were diverted downstream past the east boundary of the Laboratory. This was done to facilitate the cleanup. Short sections of the river were isolated using temporary dams and pumps to decrease the amount of water present in any given area being excavated. Besides capturing banded sunfish, staff and volunteers captured other fish, frogs, turtles, and snakes moving them either upstream or downstream out of the way of the project. Upon conclusion of cleanup operations, the river was re-contoured and native vegetation taken from the river ahead of the clean-up was restored to the river. An evaluation of the revegetation efforts indicated that the restoration was, in most areas, better than $85 \%$ effective.

With the success of cleanup efforts in the Peconic River there exists an opportunity to include wildlife viewing areas. This would provide an additional opportunity to educate employees and visitors alike of the natural resources that exist on site. There are also plans to remove existing barriers to fish migration in the on-site portions of the river.

\section{Action items:}

- $\quad$ Continue monitoring flow of Peconic River until discharge is removed.

- $\quad$ Explore the possibility of creating wildlife viewing areas. 
- Evaluate removal of weirs and any other barriers to fish migration in the on-site portions of the Peconic River.

\section{Water Quality Monitoring}

Water quality is monitored as a requirement of BNL's State Pollutant Discharge and Elimination System (SPDES) permit. Water quality is measured at various outfalls including the STP discharge to the Peconic River and at several recharge basins that receive storm water and/or once through cooling water. Results are reported to the NYSDEC on a monthly basis and summarized in the Site Environmental Report each year. The Site Environmental Report for the previous year is made available in October and may be viewed via the Internet at http://www.bnl.gov/esd/SER.asp. Sampling in 2010 did not indicate any concerns for threatened or endangered species within basins or the Peconic River.

In 2009 the NYSDEC issued BNL a new SPDES permit for its operations with a schedule for reducing discharge limits on several measured parameters including multiple metals. BNL was required to assess its effluent sources in an effort to identify further opportunities for reducing metals content and evaluate treatment alternatives to reduce the impact of the STP discharge on the Peconic. The results of these assessments are summarized in the "SPDES Study - Quantification and Removal Study Report" prepared by Dvirka and Bartilucci (Dvirka \& Bartilucci 2010). In summary, the report recommended that BNL evaluate diverting the STP discharge from the Peconic River and redirecting it to local recharge basins. By removing the discharge from the Peconic, a major contributing source of metals to the headwaters is eliminated.

Action items:

- Continue monitoring water quality.

Fish Sampling in the Peconic River

Population assessments of the onsite portion of the Peconic River are completed annually because of the remediation efforts. Fish sampling on the Peconic River is typically initiated in April and continues through early June. The early season sampling allows for more and larger fish to be obtained. Historically, late summer sampling resulted in fewer samples taken which was likely due to low dissolved oxygen content in the shallow slow moving waters. Sampling does not appear to affect the population within the onsite portions of the river as numerous smaller fish are seen during sampling events.

\section{Action items:}

- $\quad$ Continue fish sampling with NYSDEC and Cold Spring Harbor Fish Hatchery.

- $\quad$ Evaluate the continued need for fish sampling should BNL move to onsite recharge to groundwater system.

\section{Law Enforcement}

BNL currently participates in the Law Enforcement Taskforce under the Pine Barrens Commission. This group serves cooperatively to share law enforcement resources throughout the Pine Barrens region of Long Island. BNL can request additional law enforcement support from surrounding law enforcement agencies, including Suffolk County Police, Suffolk County Parks Police, Suffolk County Sheriff's Office, NYSDEC game wardens, NYSDEC Forest Rangers, and U.S. Fish \& Wildlife Service officers. Typically, BNL detains violators and transfers them to the Suffolk County Police for disposition.

Law enforcement for natural resource protection is provided, as needed, by the BNL Laboratory Protection Division. Increased law enforcement is typically needed when trespass situations such as off-road vehicles (allterrain vehicles and motorcycles) and poaching occur. ATV traffic has been an ongoing problem at BNL. Because the site is not completely fenced, there are ample ways for people to gain access to the Lab illegally and may use existing trails or create new trails and tracks for ATVs. ATVs disturb the soil, increase erosion, destroy vegetation and further fragment natural areas. This is particularly true of the sensitive areas around coastal plain ponds and vernal pools. BNL works with the Pine Barrens Law Enforcement Task Force and on-site 
security in an effort to deter ATV riders, but more needs to be done to prevent further destruction of important habitat.

\section{Action items:}

- Continue to monitor ATV use and damage.

- Continue to work with security and the Law Enforcement Task force to reduce ATV use at BNL and investigate deterrents such as felling trees across trails.

- Work with security on other trespass issues.

\section{Forest Health Monitoring}

In 2005, a consulting ecologist developed forest health monitoring protocols for the Upton Ecological and Research Reserve at BNL. The purpose of these protocols is to identify and measure both quantitative and qualitative indicators of the status of key ecological attributes of the forest, woodland and shrubland conservation targets in order to:

- Provide a baseline of the ecological integrity of conservation target condition;

- Detect and document long-term direction, rate and types of changes in attributes of the conservation targets;

- Provide baseline data to assist in setting management goals and developing adaptive management programs; and

- Identify research needs and priorities (FERN 2007).

These protocols are designed to detect a $10 \%$ change in health over a ten-year period. When the data is collected again in 2015-2016, the data will be able to detect and document the degree and direction of change in forest health, and to assist in identifying priorities for management and research within the Long Island Pine Barrens. These protocols were implemented in 2005-6 and baseline data was collected at 13 plots on the BNL site and a total of 92 plots across the pine barrens.

\section{Action item:}

- Revisit forest health monitoring plots in 2015-16 to collect monitoring data and analyze to determine changes.

- Establish deer exclosures associated with 4 BNL plots to determine effects of deer on the forest.

\section{Prescribed Fire}

The forested areas of BNL have had no active fire management for over 75 years. Presumably, throughout the entire history of the site, fire management was limited to suppression tactics. The accumulation of excessive fuel loads in the forests at BNL supports this assertion. A specific management initiative for suppression, prescribed fire, and fuel reduction is needed to manage the forest assets at BNL and ensure ecological integrity, biodiversity, and the protection of natural, cultural, and economic resources.

A Wildland Fire Management Plan (FMP) was developed to cover these issues (BNL 2003). It addresses the suppression of wildfire, use of Minimum Impact Suppression Tactics (MIST), prescribed fire, and fuel reduction. The Wildland Fire Management Plan was updated and approved in 2009. An updated prescribed fire plan was developed for a 60 -acre block of oak forest located in the northeast portion of the Laboratory. This plan is approved for a 5 -year period with an annual review conducted prior to implementation.

Unfortunately, cooperative agreements between BNL and TNC fell through when they eliminated their prescribed fire program on Long Island. The last venue for cooperative agreements will be between BNL and the NYSDEC.

Action item:

- Develop a cooperative agreement with NYSDEC in order to implement prescribed fire at BNL. 
- Implement the Fire Management Plan.

- Implement use of prescribed fire and mechanical fuel reduction.

\section{White Pine Stands}

In addition to being considered a cultural resource the stands of white pine planted by the CCC over 70 years ago are a natural resource that is in need of management. Approximately 440 acres of white pine forest exists at BNL. These stands are in need of thinning in order to remain healthy, but in order to determine the most effective way to do this the Natural Resource Division must consult with the Forest Service and NYSDEC Foresters.

It would be cost prohibitive to hire an outside contractor to come in and selectively cut trees and have them transported off-site. Unfortunately, there are no longer any local lumber mills on Long Island interested in white pine and buying an old mill to process the lumber would likely be impractical. Another option would be to reach out to the Forest Service and/or private timber companies to determine if they would agree to remove the trees for the value of the timber.

\section{Action Item:}

- $\quad$ Enlist the help of the Forest Service and/or NYSDEC Foresters to explore the possibility of entering into a no-cost contract with a private timber company to cut and remove the trees for the value of the wood.

- $\quad$ Evaluate using the NY Incident Command and Wildland Fire Academy for managing the white pines.

Invasive Species

It is important that an Adaptive Management approach be used in dealing with invasive species. The approach should always be comprehensive, examining all options and using IPM practices. IPM is an ecosystem-based strategy that focuses on long-term prevention of pests or their damage through a combination of techniques; such as manual and mechanical removal, grazing, biological control; modification of cultural practices, chemical application, and the use of prescribed fire. Pest control methods are selected and applied in a manner that minimizes risks to human health, to beneficial and non-target organisms, and to the environment. IPM methods seek to exploit a pest's innate biological weaknesses by timing efforts to coincide with specific parts of a species' life cycle. It is important to consider each available option, because it is often through a well-timed combination of different actions that the best control is achieved.

There are currently plans to re-survey the current ISPZ and expand the acreage to include additional wetlands that are documented tiger salamander habitat. Part of the relatively un-invaded white pine plantation may also be included. The ISPZ plan will be rewritten to reflect the changes.

As new funding sources become available, more active management of the invasive plants on-site will be considered. In the meantime, BNL will continue to participate in LIISMA and the Scientific Review Committee. In addition, the site should be monitored for spread of the existing infestations as well as the early detection of new species. This includes pests and pathogens as new species are being discovered and moved around the landscape. New species that are detected should be immediately mapped via GPS and management should be implemented as soon as possible to prevent further spread and keep control costs low.

As part of a prevention strategy, planting lists containing native and non-native species have been distributed to BNL's Facilities \& Operations Division as a tool to aid in planning for new construction landscaping. Only native species and, if possible, local genotypes are being recommended for use in restoration projects.

\section{Action Items:}

- Re-survey the current ISPZ, explore addition of new areas to ISPZ and rewrite the ISPZ plan.

- Continue monitoring of existing infestations and surveys for new infestations of invasive plants as well as pests and pathogens.

- Manage invasive species infestations when possible with priority given to new species found on site. 
- Utilize annual funding levels to implement invasive species management.

- Use native species and local genotypes where possible for restoration projects and new construction landscaping.

\section{Population Monitoring \& Management}

Several species are of special interest for natural resource management. Some are highly noticeable (like deer and turkey), while others (songbirds and salamanders) are of interest to select groups of people or are of regulatory concern. Management of these populations may be primarily passive unless they are determined to need active management to enhance, maintain, or reduce the population. Population management often includes managing and/or increasing suitable habitat so there may be some overlap with the previous section.

\section{Special Status Species}

\section{Frosted elfin}

The frosted elfin is a small butterfly that lives at the edges of fields near woods or scrubs of Long Island. The frosted elfin, which is an obligate species and is limited to the use of wild lupine for egg laying and larval development, has been added to the special-status species list. Historically, NYSDEC and the New York Natural Heritage Program have documented frosted elfin within a single $30^{\prime} X 100^{\prime}$ patch of lupine on BNL. This area of lupine will be maintained. In 2003, lupine seed was scattered in the RHIC Ring as part of the RHIC revegetation, and seeds were also scattered along the East Firebreak. Unfortunately, these attempts were unsuccessful. Attempts to expand lupine populations up the East Firebreak will continue as more information is obtained about seed collection and preparation.

\section{Action items:}

- Continue to monitor the existing lupine patch for presence/absence of frosted elfin.

- Assess habitat needs for lupine.

- Increase the population of lupine on site using the existing seed source for propagation. Consider maintenance, such as mowing known habitats to maintain species, or planting additional habitats.

\section{Banded sunfish \& swamp darter}

The banded sunfish is a small sunfish that typically lives in heavily vegetated backwaters and deeper pools of the Peconic River system on Long Island. At BNL the banded sunfish is currently found only in Zeke's Pond. It has been managed passively by ensuring that water flow is maintained in the Peconic River. This is accomplished, in part, by discharges to the river from the STP. Annual surveys conducted on the river between the STP and the East Firebreak document the population and sizes of the banded sunfish within this stretch of the river. With the upcoming changes of the STP discharge from surface water to groundwater recharge, Peconic River flow will most likely be affected and annual surveys will become that much more important. Occasionally, periods of high flow allow predatory fish such as pickerel (Esox niger) and largemouth bass (Micropterus salmoides) access to Zeke's pond and these fish can impact the banded sunfish population. Alternatively, extreme drought can also impact populations when both water and dissolved oxygen levels become exceptionally low. In these cases, it may be necessary to re-introduce banded sunfish to Zeke's Pond and perhaps to other suitable on-site areas of the Peconic River.

The swamp darter is a small fish that lives in still, dark waters of Long Island and often occurs with the banded sunfish. A single healthy population of this fish was identified during summer 2000 in Zeke's Pond. The drought of 2003 seems to have wiped out this population, however, some surveys for this species will be conducted to confirm (or refute) its presence.

\section{Action items:}

- Continue monitoring banded sunfish populations biennially and survey for the existence of swamp darter on-site.

- Remove predatory fish species as necessary.

- Explore re-introduction of both species to on-site portion of the Peconic River as necessary. 


\section{Eastern tiger salamander}

The eastern tiger salamander, a New York endangered species, is locally abundant on the BNL site. This species has been documented using at least 27 ponds or pond systems on site. In 2003, the addition of drift fence arrays around two ponds has provided substantial information concerning the emergence of tiger salamanders from ponds. The tiger salamander population is apparently doing quite well at BNL. However, because the eastern tiger salamander is listed as a New York State endangered species, BNL will continue to protect and monitor its populations and habitat, and will conduct research to better understand the biology and ecology of this species. BNL currently has a mechanism in place (a required digging permit) to ensure that BNL activities near tiger salamander habitat are reviewed prior to initiation and any activity that could be harmful is minimized; more significant actions require consultation with NYSDEC. In addition, all new construction projects are required to implement storm water controls such as silt fencing to mitigate the runoff of silt into the storm water system and, ultimately, into nearby ponds used by tiger salamanders.

Several of the known tiger salamander habitats are drainage or recharge basins. Periodic maintenance of these basins is necessary to ensure proper recharge capabilities. However, the timing of maintenance must be coordinated to ensure function of the basin as well as protection of tiger salamanders that may be present there. One known requirement for managing the tiger salamander population is a protocol for basin maintenance that will ensure adequate tiger salamander habitat.

\section{Action items:}

- $\quad$ Continue annual egg mass and larval surveys at breeding ponds.

\section{Migratory Birds}

As discussed previously, songbird surveys are conducted twice annually and will continue to be conducted in this manner. Some songbird species are also considered special status species within New York State (see Table 1) and BNL will manage habitat for these species when possible and necessary.

\section{Bird nests/boxes}

Nest boxes are important for many species of birds because of the lack of proper habitat. This is particularly true of birds that utilize cavities for nesting. The eastern bluebird (Sialia sialis) is one of the better known birds for which nest boxes are important. The bluebird was once a species of special concern in New York State. The loss of natural cavities along with competition for available cavities from other cavity nesters like house wren, European starlings, house sparrows, and tree swallows resulted in declining populations. This species has recovered significantly due to massive efforts to provide artificial nest boxes in appropriate habitat, which exists at BNL as in other locations on Long Island.

BNL had 48 nest boxes distributed across the site in appropriate habitat (open fields near forested areas) in 2009. Several boxes were removed from around a recharge basin that was being enlarged to accommodate increased storm water flows. Once construction of the Long Island Sound Farm is completed additional boxes will be placed along the fence lines and, hopefully, on the LISF site itself once construction is complete. House wrens, tree swallows, chickadees, and tufted titmouse also use the bluebird boxes (Table 4). The successful use of boxes by bluebirds increased while use by other species decreased. The use of the nest boxes by different species is indicated in Figure 6 . The percent use of nest boxes by bluebirds increased to nearly $60 \%$ in 2008 while use by other species like tree swallows declined.

All nest boxes including bluebird, wood duck, and kestrel boxes continue to be monitored by volunteers several times each year. To date, four years of monitoring suggest very limited use of wood duck boxes near the biology fields and in the RHIC ring, and apparently no use of kestrel boxes is occurring.

\section{Action items:}

- Continue annual songbird surveys.

- Continue to maintain nest boxes where appropriate and monitor populations.

- Add nest box locations and other data to GIS library. 
- Work with LISF to install nest boxes on-site once construction is complete.

Table 4. Results of bluebird nest box monitoring 2001-2009.

\begin{tabular}{|c|c|c|c|c|c|c|c|}
\hline Year & $\begin{array}{c}\text { \# of } \\
\text { Boxes }\end{array}$ & Empty/other & Bluebird & $\begin{array}{c}\text { House } \\
\text { Wren }\end{array}$ & $\begin{array}{c}\text { Tree } \\
\text { Swallow }\end{array}$ & Chickadee & Tufted Titmouse \\
\hline 2001 & 37 & 12 & 19 & 6 & 1 & & \\
\hline 2002 & 46 & 13 & 19 & 6 & 6 & 2 & \\
\hline 2003 & 46 & 14 & 21 & 4 & 4 & & 2 \\
\hline 2004 & 48 & 12 & 23 & 6 & 6 & 1 & \\
\hline 2005 & 53 & 9 & 39 & 6 & 6 & 1 & \\
\hline 2006 & 56 & 8 & 38 & 9 & 6 & 1 & \\
\hline 2007 & 54 & 20 & 27 & 14 & 3 & 3 & \\
\hline 2008 & 54 & 19 & 32 & 14 & 1 & 2 & \\
\hline 2009 & 48 & 20 & 27 & 7 & 5 & & \\
\hline
\end{tabular}

Figure 6. Bluebird nest box use based on a percentage of available boxes.

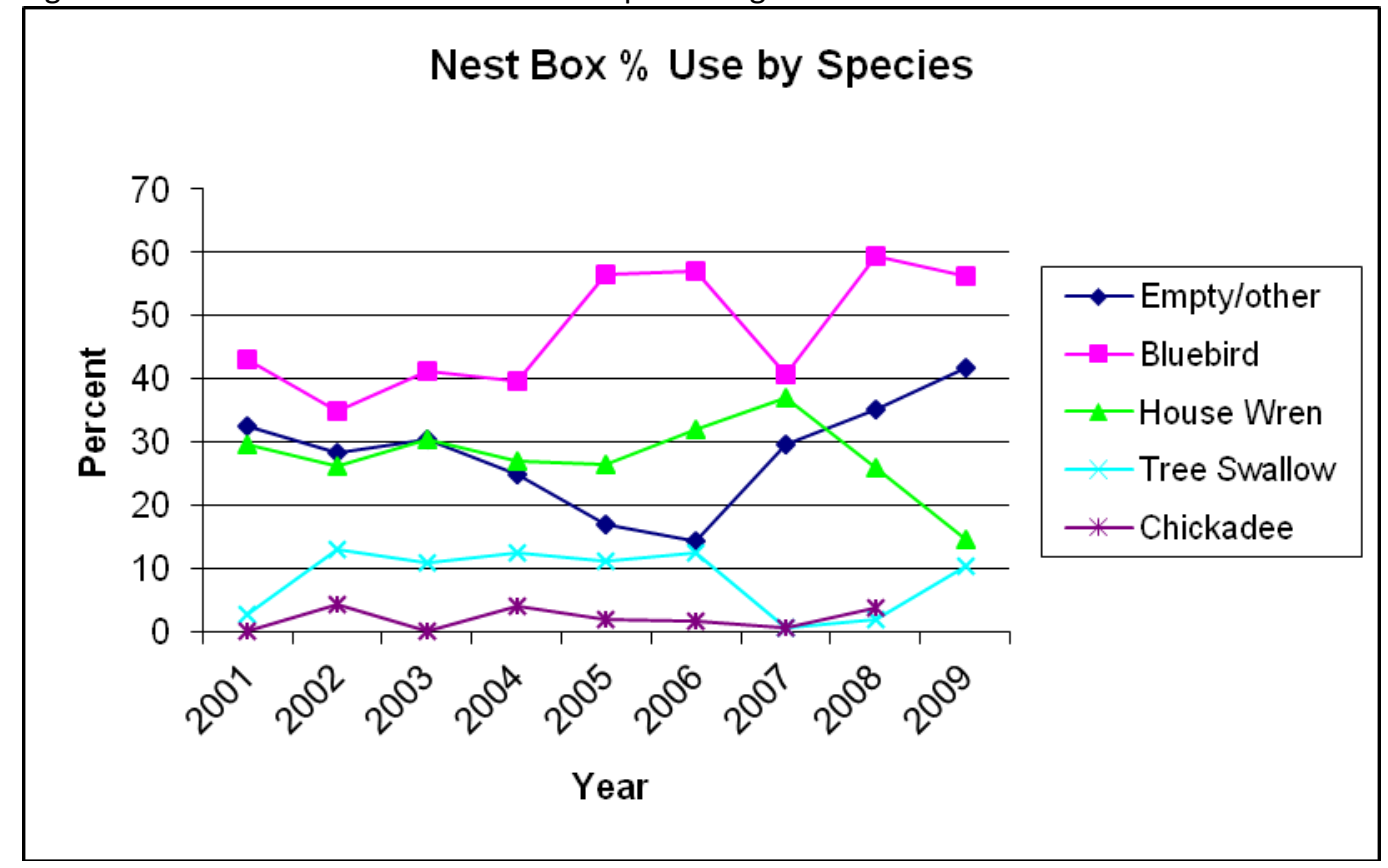

\section{Other Species}

Wild turkey

The wild turkey population at BNL appears to be flourishing and it is likely that it will continue to grow. It should be monitored for population health and watched to identify any potential nuisance situations that could require action.

\section{Action items:}

- $\quad$ Continue to monitor wild turkey populations.

- $\quad$ Provide NYSDEC with sighting reports as necessary.

- Cooperate with NYSDEC management initiatives. 
Canada goose

Numerous requests for management of the geese were received in 2007 mainly dealing with presence of goose droppings on sidewalks and walkways. The population at the time was estimated at 157 individuals. In several instances geese were causing safety issues due to their defensive posturing to protect their nests. Due to the location of the nesting geese, some of the nests were destroyed, under permit, forcing the geese to move to another location. Because of the continued nuisance situations, the Natural Resource Program obtained a permit under new FWS regulations established late in 2006 to manage nesting geese. These regulations allow nest management to occur based on registering with the FWS and reporting data back to them. A total of 10 nests were either destroyed or the eggs oiled as the opportunity presented itself or in response to complaints. Aggressive nest management was not practiced in 2007. However, because the population continued to increase, oiling of goose eggs resumed from 2008 through 2010 and will continue as necessary.

\section{Action items:}

- Continue to monitor goose populations.

- Continue management by oiling eggs as necessary.

White-tailed deer

Without management the white-tailed deer population will continue to fluctuate and cause ecological damage to the forests and ornamental plantings at BNL. Both the USFWS and USDA-WS have written environmental assessments for the management of deer populations at various locations across NY State. In the past, BNL has looked at the impacts of deer, conducted surveys to determine population size, as well as surveys to assess the attitude of BNL employees towards deer management. In 2008, BNL's Policy Council recommended establishing a deer management program. Initial work to develop this program was suspended due to the need to write multiple Environmental Assessments (EAs) for higher priority projects. Deer management, in 2011, has been re-prioritized and an EA or adoption of one or both existing EAs will be conducted in 2011.

Action items:

- Complete EA for deer management alternatives.

- Establish and implement a deer management program.

- Continue estimation of the deer population.

Feral and nuisance animals

The existing feral cat colonies continue to be managed by an ad-hoc group of employees. There has been a minor decrease in the number of cats due to presence of several wild dogs that roamed through the BNL site in 2007. These dogs killed several of the feral cats before they were successfully captured and transferred to the Brookhaven Town animal shelter. One of the wild dogs gave birth to a litter of puppies. The Town allowed the mother to care for the puppies until they could be weaned and all of the puppies were adopted by local residents.

A general agreement on feral cats was established with the ad hoc cat managers. This agreement basically provides for the continued care of existing cats and does not allow any cats to be added to the colonies regardless of whether they are introduced or wander into a colony. This policy ensures that the colony size will be reduced over time. Data collected by simple ad hoc monitoring of cat colonies by care givers is routinely submitted to the Natural Resource Manager for review.

In general, Facilities and Operations staff resolves most feral and nuisance animal problems at BNL, however, problem identification, coordination, and resolution should, in part, be coordinated through the NRMP and the Natural Resource Manager in association with volunteer groups at the Laboratory. In the future many of these nuisance animals (raccoons, opossum, skunks and woodchucks) will be euthanized rather than be released in another part of the lab as the animals often return to the original site. Beneficial animals such as foxes should not be euthanized, but should be released elsewhere whenever possible. In instances when migratory birds become a problem Natural Resource Management will consult with FWS and USDA-APHIS in order to properly deal with the situation. 


\section{Action items:}

- Establish best management policies for dealing with feral, free ranging, and/or nuisance wildlife species. Individual species status must be taken into consideration as well as sensitivities, worker health, and ecosystem health (i.e. decision mechanism would be preferred vs. a one size fits all approach).

- Continue implementation of BNL policy on feral animals.

\section{Climate Change}

As climate predictions become increasingly dire, natural resource managers continue to evaluate adaptation options for climate-sensitive ecosystems and seek actual on-the-ground implementation mechanisms. Resiliency is defined as the amount of change or disturbance that a system can absorb before it undergoes a fundamental shift to a different set of processes or structures. Helping to ensure the resilience of an ecosystem is predicated on maintaining the genetic diversity, biologic diversity, and heterogeneity of landscape mosaics within the system. To keep this diversity, ecosystem processes (i.e., water cycle, mineral cycle, energy flow, and community dynamics) need to remain as intact as possible. Much of the natural resources management currently being done at BNL serves this very purpose, however, little is known about the impacts climate change will have on our ecosystems.

In 2010, FWS established regional programs to tackle the climate change issue. These programs are called Landscape Conservation Cooperatives (LCCS) and are made up of Department of the Interior agencies, other federal agencies, states, tribes, non-governmental organizations, universities and others. They are applied conservation science partnerships focused on a defined geographic area that informs on-the-ground strategic conservation efforts at landscape scales. While BNL does not have the resources to actively participate in this group, by keeping abreast of the climate change research they perform, our management efforts will be wellinformed. In addition, there is the potential for some of this research to be performed on-site so that we may determine the effects climate change is having locally.

Action item:

- Keep informed of LCC research findings and management recommendations.

- Explore possibility of performing research on local effects of climate change on site.

\section{Research}

\section{Long Island Solar Farm}

As mentioned previously, the creation of the LISF presents us with a unique opportunity to conduct research not only on the impacts directly associated with the facility, but also on the comparative impacts white-tailed deer have on many aspects of an ecosystem. Below is a list of potential research areas which is by no means complete.

1) Comparative impacts from deer. This is a large facility that will exclude deer, but allow other wildlife to enter/exit via wildlife friendly fencing. Questions needing answers:

a) Does LISF provide improved habitat for small mammals?

b) Does LISF provide improved habitat for migratory songbirds including nesting habitat?

c) Does LISF allow adequate growth and diversity of understory vegetation?

d) Does the LISF improve habitat for eastern tiger salamanders beyond state mandated protection areas?

e) Does LISF vegetation management provide adequate habitat for native insect pollinators?

f) Can the LISF benefit threatened and endangered insect species through provision of critical host plants?

2) Wildlife Use of LISF \& effectiveness of wildlife friendly fencing. Questions needing answers: 
a) Does wildlife utilize wildlife openings in fences? Is spacing adequate? Are openings appropriately sized? Are openings appropriately located?

b) Do birds utilize LISF arrays for perching, hunting, and/or foraging?

c) Are reptiles and amphibians impacted by fencing? Specifically, does fencing impact movements of the eastern box turtle, a NY State species of special concern?

d) Do meso-carnivores (e.g. red foxes) differentially utilize habitats in and out of the LISF due to openings and variations in prey base?

3) LISF arrays are expected to concentrate acid rain and mercury deposition along a "drip line" on each array. Does this impact wildlife?

a) Do localized acid conditions impact soil chemistry causing aluminum toxicity to the local plant community?

b) Does localized deposition of mercury differentially increase mercury in insects, increasing bioaccumulation in insectivorous birds and bats?

4) LISF Heat Island Effects

a) Does the heat island impact nearby wetlands and wetland dependent species (i.e. marbled salamanders, spring peepers, wood frogs).

b) Does the heat island impact waterfowl?

c) Does the heat island impact success of nesting birds?

d) Does the heat island impact surrounding wetland insects (mosquitoes, midges, odonates)?

\section{Action items:}

- Support and conduct research as needed.

- Identify, attract, and support ecological research at BNL.

\section{Education and Outreach}

Natural resource management has historically been of high interest to educators and the general public. Because of the interest as well as the often-controversial nature of natural resource management activities, a public outreach and education program is a necessity. A variety of educational activities have been developed and coordinated through the Educational Programs Office and Community Education Governmental and Public Affairs (CEGPA) office. Coordination through CEGPA is needed to involve the public through participation in nature-oriented activities, outreach opportunities, and education.

Every year, interns are hosted to conduct ecological and wildlife research to assist in understanding how the natural environment works. The information gained from these projects is used to make management decisions at the Laboratory. Interns are high school or undergraduate students participating in the BNL's Office of Education summer programs. During 10 weeks, the students conduct experiments, population surveys, ecological monitoring, and other natural resource investigations. Students are required to complete a paper and/or poster as part of their internship.

\section{Action items:}

- Continue to provide educational materials to staff and the public on environmental issues. Materials will be updated and redistributed as necessary. Nature walks and bird watching field trips should be conducted routinely. The Natural Resources pages on the BNL website should be updated for continued use as public education.

- Continue to host interns to assist with and conduct research on-site as part of BNL's Office of Education summer programs. 


\section{References}

Adaptive Management. Definition of Adaptive Management. Available from:

http://www.for.gov.bc.ca/hfp/amhome/Admin/index.htm. Accessed March 1, 2011.

Blais, D. 1993. Species Dossier on the eastern tiger salamander (Ambystoma tigrinum). NYSDEC Endangered Species Working Group.

BNL. 1977. Final Environmental Impact Statement for Brookhaven National Laboratory. ERDA-1540. Energy Research and Development Administration, Upton, NY. July 1977.

BNL. 1995. Future Land Use Plan. BNL-63130. Brookhaven National Laboratory, Upton, NY. 1995.

BNL. 2002. 2001 Site Environmental Report. BNL-52671. Brookhaven National Laboratory, Upton, NY. September 2002.

BNL. 2003. Wildland Fire Management Plan for Brookhaven National Laboratory. BNL-71629-2003.

Brookhaven National Laboratory, Upton, NY. September 2003.

BNL. 2008. Invasive Species Prevention Zone Plan for Brookhaven National Laboratory. Brookhaven National Laboratory, Upton, NY. September 2008.

BNL. 2009a. Land Use Controls Management Plan. Brookhaven National Laboratory, Upton, NY. June 2009.

BNL. 2009b. Wildland Fire Management Plan for Brookhaven National Laboratory. BNL-82418-2009.

Brookhaven National Laboratory, Upton, NY. September 2009.

Breeder, C.M. 1936. The reproductive habits of the North American Sunfishes. Zoologica, 21(1): 1 B 48.

Breisch, A. 1994. Personal communications with Jan Naidu.

Department of Energy. 2009. Environmental Assessment for BP Solar Array Project. DOE/EA-1663. Office of Science, Brookhaven Site Office, Upton, NY. December 2009.

Dvirka and Bartilucci. 2010. SPDES Study - Quantification and Removal Report. Woodbury, NY. July 2010.

FERN. 2008. Freshwater Wetland Health and Biodiversity Monitoring Protocols for the Long Island Pine Barrens. Upton, NY. May 2008.

Fish \& Wildlife Service. 1997. Significant Habitats and Habitat Complexes of the New York Bight Watershed. Southern New England - New York Bight Coastal Ecosystems Program, Charlestown, RI. November 1997.

Lawler, Matusky \& Skelly. 1995. Phase II Sitewide Biological Inventory Report. Lawler, Matusky \& Skelly Engineers, Environmental Science \& Engineering Consultants, One Blue Hill Plaza, Pearl River, NY.

Madison, D.M. and L. Farrard. 1998. Habitat Use during Breeding and Emigration in Radio-implanted Tiger Salamanders, Ambystoma tigrinum. Copeia 1998 (2), 99. 407-410.

McDougal, J. personal communication to J.R. Naidu, letter dated July 7, 1998.

New York Natural Heritage Program. 2011. Online Conservation Guide for Coastal Plain Pond. Available from: http://www.acris.nynhp.org/guide.php?id=9889. Accessed February 22, 2011.

New York State Department of Environmental Conservation. 1994. Tiger salamander breeding pond protocol. $8 p p$.

New York State Department of Environmental Conservation. 2010. Guidance for land cover set aside for conservation of the eastern tiger salamander. October 26, 2010. 
Noble, I.R., Slatyer, R.O. 1977. Post-fire succession of plants in Mediterranean ecosystems. In: Mooney, H.A., Conrad, C.E. (Technical coordinators), Proceedings of the Symposium on the Environmental Consequences of Fire and Fuel Management in Mediterranean Ecosystems, Palo Alto, CA, 1-5 August 1977. USDA Forest Service General Technical Report WO-3, Washington, DC, pp. 27-36.

Rowe, J.S. 1983. Concepts of fire effects on plant individuals and species. In: Wein, R.W., MacLean, D.A. (Eds.), The Role of Fire in Northern Circumpolar Ecosystems. Wiley, New York, pp. 135-154. 
APPENDICES 
Appendix A - Tiger Salamander Habitat Management Plan

\section{Protection of the Eastern Tiger Salamander}

The eastern tiger salamander (Ambystoma tigrinum tigrinum) was officially listed as a state-endangered species in 1983 (NYS ECL, Article 11, Section 11-0535; NYSCRR Title 6, part 182.6). Populations have declined as a result of loss of habitat through development, road mortality during breeding migration, introduction of predatory fish to breeding sites, collection by the bait and pet trade, water level fluctuations, pollution, and general disturbance of breeding sites.

The eastern tiger salamander is afforded "protection from habitat destruction, harm or harassment" by NYSDEC. All State-recognized breeding sites and the 1000 -foot radius buffer zone surrounding each site are considered critical habitat for breeding, and are accorded the highest priority for protection. An additional 350 feet beyond this area is also considered as critical to the resident adult population (Madison and Farrand 1998). Use of land around the breeding pond buffer zone is subject to State Environmental Quality Review Act proceedings (Breisch 1994, pers. comm.; NYSDEC 1994), and therefore this 850 -foot buffer zone is monitored by BNL, in collaboration with NYSDEC as needed.

\section{Biology of the Eastern Tiger Salamander}

The eastern tiger salamander, an amphibian, is the largest of six mole salamanders (genus Ambystoma) found in New York. These salamanders seem to prefer the sandy, friable soils that are typical of pine-oak communities (Pinus rigida/Quercus spp.) on Long Island. However, tiger salamanders are also found in fields, lawns, gardens, and pastures. Tiger salamanders have been historically recorded from Central Nassau County and Jamaica, Queens County, far outside the limits of the Pine Barrens. Both adults and sub-adults lead a fossorial (underground) existence, foraging for invertebrates, insects, worms, and slugs through their own burrows or existing small-mammal burrows and root-ways (passages created when roots rot away). Occasionally, salamanders may move under leaf litter, through hollow logs, or beneath debris. Other mole salamanders potentially occurring in the same habitat include marbled (A. opacum), spotted (A. maculatum), and blue-spotted (A. laterale) salamanders (Lawler, Matusky \& Skelly 1995). All mole salamanders have similar body configurations: broad, flat heads with protruding eyes, large mouths, thick bodies, and strong legs with thick blunt toes (four front and five rear). Adults are easily distinguished from juveniles by their color patterns and size. Larval salamanders are similar to adult salamanders in body shape, but body size, development, and coloration can usually be used to distinguish between the species (Figure A-1). Adult tiger salamanders may live 10 to 15 years in the wild and grow to total lengths of 9 to 10 inches. Natural predators include short-tailed shrews, fish, snakes, turtles, herons, and shorebirds. Insect larvae may also prey on the early larval stages of tiger salamanders.

\section{Distribution}

In the northeastern United States, tiger salamanders do not occur north of Long Island or in Pennsylvania. South of Long Island, tiger salamanders are found in southern New Jersey, Delaware, and Maryland. Tiger salamander populations on Long Island center around the towns of Brookhaven and Southampton. Since 1984, NYSDEC has confirmed over ninety active tiger salamander breeding sites on Long Island (Blais 1993), however, since then it has been observed that a number of such sites have been eliminated as breeding sites, except at the Laboratory site, where the largest number of sites were observed. Lawler, Matusky \& Skelly (LMS) confirmed 13on-site locations as tiger salamander breeding habitat during 1994 surveys (Lawler, Matusky \& Skelly 1995), whereas NYSDEC previously listed only one area. The on-site number of breeding ponds has now been confirmed at 27 locations. 
Figure A-1. Tiger salamander.

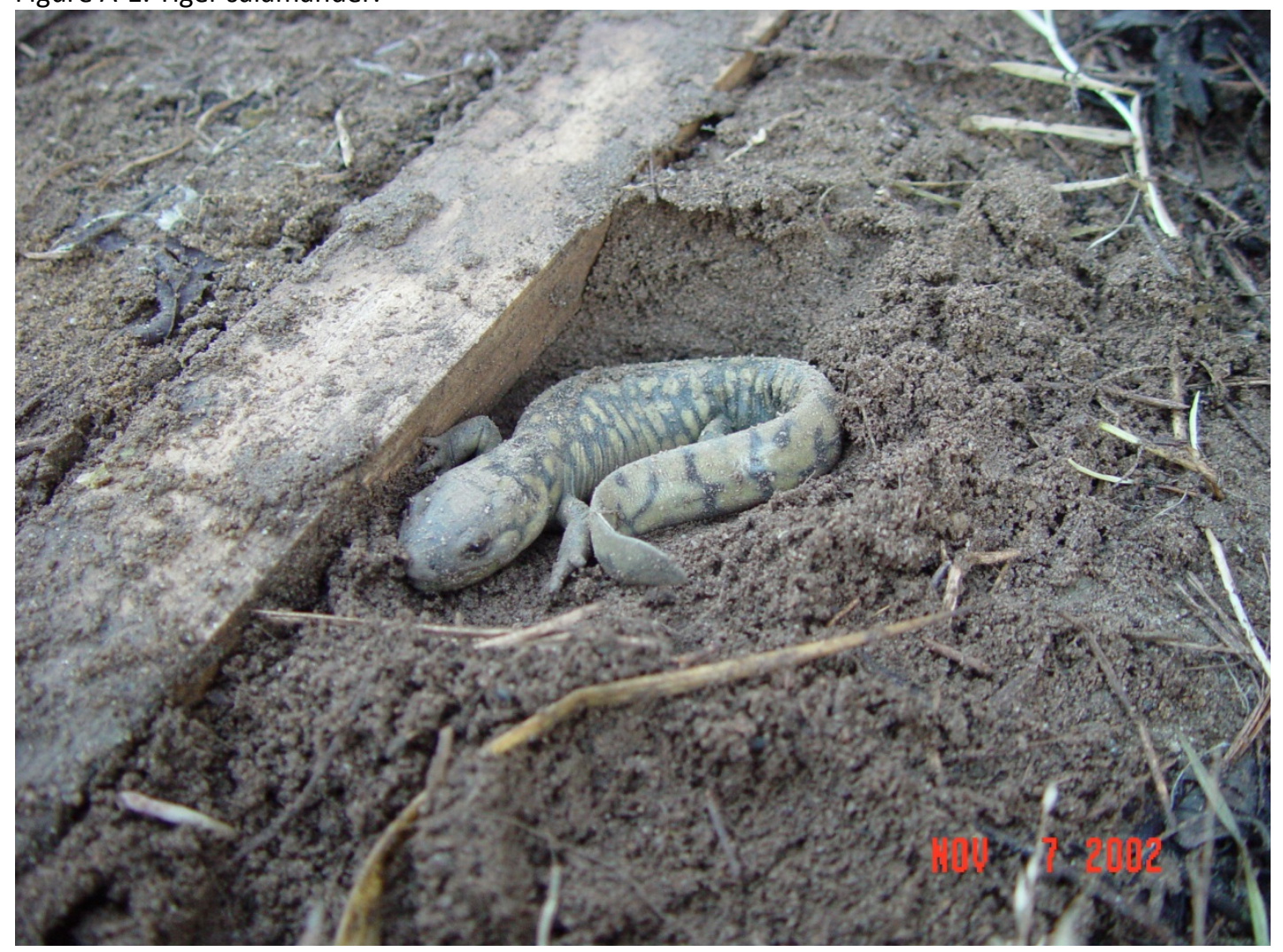

Breeding Patterns

In New York, tiger salamanders migrate to breeding ponds as early as late November (Titus, Green 2007 personal communication) or as late as mid-April. The timing depends on winter weather conditions, when the possibility of hard rains or snow occurs. Migration usually takes place at night. As with most mole salamanders, rain or melting snow stimulates the adults to emerge from underground retreats and migrate to breeding ponds. Males usually outnumber females and reach the ponds first. Courtship begins when a female encounters one or more males. Males nudge the female and set spermatophores (sperm packets) in the sediment or on sticks and leaves. The female maneuvers herself to insert spermatophores into her cloaca, where sperm from the spermatophore fertilize her eggs. Within a few days after fertilization, females lay 200 to 400 eggs in several batches. The eggs are attached underwater to sticks and emergent/submerged vegetation about one foot below the surface of shallow (approximately $3-\mathrm{ft}$ ) ponds. Depending on water temperature, eggs hatch in 14 to 30 days (Blais 1993).

Newly hatched larvae are 0.50 to 0.68 inches long. They metamorphose from mid-June to early August (Blais 1993), with occasional emergence as late as mid-September (Green, Feinberg 2003 - personal communication). The aquatic larvae have fan-like gills, but gradually develop lungs in preparation for a terrestrial adult life. Larval salamanders feed on aquatic invertebrates (insect larvae, copepods), and are known to feed on the larvae of other amphibians. Larvae may undergo early metamorphosis in drying ponds. Mortality is high if the ponds dry up too rapidly. Adults leave the ponds soon after breeding, triggered by favorable weather conditions such as rain or high humidity; sub-adults migrate following metamorphosis.

Based on the above observations, the critical times for the salamander species are as follows:

- December to April for spotted and tiger salamander adults when they are most active, most often above ground and moving to and from breeding ponds (within the 1000-ft buffer zone radius). 
- May to the end of July for metamorphosis as they leave the ponds and travel to upland shelters (within the 1000-ft buffer zone).

\section{Survey Methodology}

Tiger salamander surveys were first conducted in 1994. Twenty-three locations on the BNL site were checked at least once for adults or egg masses; 17 locations were checked for both adults and egg masses. During May and June, 11 sites were checked for larval tiger salamanders, primarily to verify species identification, which had tentatively been determined, based on size and configuration of egg masses. Survey locations included sites identified by NYSDEC as historical/confirmed or potential tiger salamander breeding habitats. Evaluations of potential habitat were first made on the basis of field and aerial photograph investigations. Figure A-2 (not included in public copies of this report) is a scaled depiction of the breeding locations. Superimposed on the map, at each confirmed or potential location, is a $1000-\mathrm{ft}$ buffer zone. In order to minimize negative impacts to salamanders the NYSDEC requires that any project occurring within 1000 feet of tiger salamander breeding ponds include provisions to preserve $100 \%$ of the existing upland forest habitat within 535 feet of the breeding pond and preserve "a minimum of 50\% of the adjacent upland area within 1,000 feet of breeding ponds in contiguous blocks of suitable habitat, while allowing for the preservation of wooded corridors which provide connections to adjacent tiger salamander upland habitats" (NYSDEC 2010). As previously mentioned, information on tiger salamander pond locations is not public information; hence, the map showing the confirmed breeding ponds does not appear in distributed copies of this report.

Survey timing is coordinated with NYSDEC, the agency responsible for conducting concurrent tiger salamander studies on Long Island. Surveys at BNL are organized and carried out, under permit, by the Natural Resource Manager. Egg mass surveys are carried out between the end of January and mid-April, and larval surveys are conducted annually during the month of June. Emergence studies occur annually around two or more ponds to evaluate the use of cover boards and drift fences, and factors influencing their use.

All known and potential tiger salamander habitat is surveyed annually for egg masses. However, ponds that were completely dry and documented as not having egg masses by mid-April are not surveyed for larvae in June. All ponds documented with egg masses are resurveyed for larvae, if just to document the pond's having dried between the time of egg mass production and expected larval development.

The sampling methodology follows the basic protocols provided by NYSDEC (1994) and survey results are recorded and reported on log sheets. Results of activities under a NYSDEC Threatened and Endangered Species Permit are submitted to the agency yearly with a request for permit renewal.

\section{Habitat Protection Protocols}

As part of the ongoing process to maintain and improve the suitability of the tiger salamander habitat and the tiger salamander breeding sites, each site (confirmed or potential) has been reviewed with NYSDEC staff. Improvements described below began to be implemented in 1999 as funding allowed, and all management actions established in 1999 have been implemented. The schedule for implementation of new and existing actions is given in Appendix C of the Natural Resource Management Plan. Figure A-2 shows the location of the sites. (Note: This map is confidential, and is not included in copies for general distribution.) Protection of this species consists of the following actions:

- Identify and map tiger salamander habitat.

- Improve existing knowledge of the annual timing of migration, breeding, and emergence. During these times, construction or maintenance activities by the Laboratory engineering staff will be minimized. An example would be to restrict recharge basin maintenance activities to occur between August and December, to avoid the tiger salamander breeding and larval developmental periods.

- Test water quality as part of the routine monitoring of the basins. The data will be used to assess water quality, as it may affect tiger salamander breeding and larval development. Water quality parameters are routinely taken at recharge basins receiving discharge waters permitted under BNL's SPDES permit and 
include a broad suite of analytes. All ponds surveyed for egg masses and/or larvae have standard water quality parameters measured at the time of the egg mass or larval surveys. Water quality parameters routinely sampled during these events include temperature, salinity, conductivity, turbidity, and $\mathrm{pH}$. No chemical analysis of natural ponds is conducted.

- Consult with NYSDEC on any action that could possibly impact known or suspected tiger salamander habitats. Consultations will be coordinated through the Natural Resource Management Program staff. To ensure this action, EPD, Facilities and Operations Division, and Environmental Management Directorate program managers have received a map of known tiger salamander breeding areas, with the understanding that this information will remain confidential. When certain activities are planned within the 1000-ft buffer zone, BNL staff will consult with the EPD, and NYSDEC as needed, in particular if the proposed action has the potential to significantly impact a confirmed breeding location (i.e., land clearing activities, well drilling near known or suspected habitat). All major activities involving soil penetration, clearing, scraping, and so forth require the completion of a digging permit, which contains a sign-off line for threatened and endangered species. Any significant activities within designated tiger salamander habitat areas would automatically trigger the requirement for consultation with NYSDEC prior to initiating the action. The purpose of this review is to ensure that the planned activity does not interfere with breeding or migration activity.

- Continue routine maintenance of roadways (including salting, snow plowing and mowing road shoulders) and periodic clearing of firebreaks, as these activities pose no direct impact to the breeding pools. However, whenever possible, conduct these activities before or after the breeding cycle, and consider potential impacts in surrounding areas during other sensitive stages of the tiger salamander's life cycle.

- Control and monitor the use of pesticides and salt. Pesticide application is tailored to minimize use. Agricultural fields are usually cultivated after the salamanders have completed their migration; however, the use of pesticides may require that a monitoring program be initiated to determine if pesticide residues in the water could impact the development of larvae and juveniles. Salting the road during winter and the potential of runoff entering the breeding areas will require monitoring of the runoff to evaluate the impact on larvae and juveniles. Currently, the following water quality parameters are monitored for natural bodies of water: temperature, $\mathrm{pH}$, dissolved oxygen, conductivity, and salinity. In addition, water from recharge basins is monitored for those attributes plus chlorides, nitrates, sulfates, and metals.

- Beginning in 2000, the Natural Resource Management program has coordinated an annual survey of existing and potential tiger salamander habitats. The results of such surveys provide information for determining the length of the breeding period and provide an active window for construction activities in and around the breeding areas, and identify changes in site use and possible activities that could affect this species. Based on these surveys, re-evaluate the NRMP every five years or as appropriate and update it with the additional threatened or endangered species found on BNL property.

- Manage invasive species around tiger salamander habitat to maintain and improve habitat.

\section{Confirmed Breeding Sites}

The following describes known or suspected tiger salamander habitat protection plans for confirmed and unconfirmed breeding sites. Note that NYSDEC has records confirming approximately 107 breeding localities in New York State since 1983-1984. It is not known how many of these sites are still active. Some of these populations have been extirpated, and some were apparently never used by large numbers of breeding salamanders. NYSDEC personnel believe that a relatively small number of sites have confirmed breeding activity every year they are surveyed. Differences in observations may be due to biological phenomena or search/observer bias (McDougal 1998, pers. comm.). A "TS" designation indicates that the site is confirmed; "ts" means unconfirmed; "TS-W" means a wetland complex; and, "TS-A" means a man-made pond.

TS-1 is a vernal pool. This is a suitable habitat for breeding tiger salamanders, with appropriate submerged vegetation for attachment of egg masses. A number of potential predators are present, including bullfrogs, 
green frogs, painted turtles, and solitary sandpipers. This site has had egg masses documented most years since 2000. The habitat is relatively undisturbed, but has occasional trespass visitation along pond margins. 
TS-2 is a vernal pool. This is a suitable habitat for breeding tiger salamanders and develops appropriate attachment sites for egg masses most years (egg masses have been documented annually). The public uses this pond illegally as an ATV racetrack. The use of this pond by ATV users will continue to be monitored. BNL participates with the Law Enforcement Task Force of the Central Pine Barrens to patrol the area in an attempt to eliminate or at least limit the incidence of ATV use in the area. Should continued action be necessary, NYSDEC will be consulted to develop potential solutions to the problem.

TS-4a \& b, also known as Zeke's Pond, is a large pond that once fed the Peconic River. It is known habitat for two state threatened fish, the banded sunfish and swamp darter. Water is generally persistent enough to maintain a predatory fish population, largemouth bass and brown bullhead catfish that likely would limit successful tiger salamander use. The drought of 2002 resulted in this pond drying up. Prior to the reintroduction of banded sunfish, this pond was surveyed for other fish. During that survey several larval tiger salamanders were identified, confirming this pond as a viable tiger salamander habitat. The pond will continue to be surveyed on an annual basis.

TS-5, a coastal plain pond, has been surveyed for egg masses and they are occasionally present. Dead adult tiger salamanders were documented in 2000 along the banks of the pond and larval tiger salamanders were documented in May 1994. The presence of fish has been routinely documented. It is likely that the pond is being stocked by individuals in the nearby neighborhood. No fish are currently in the pond.

TS-6, also known as the "water tank pond" was the only area on the BNL property identified as a significant habitat by NYSDEC (so designated because of its function as tiger salamander breeding habitat). The observation of several adult males and females, egg masses, and larvae attest to this. This pond is also known as habitat for marbled salamanders, red-spotted newts, and four-toed salamanders. The pond will continue to be surveyed annually for egg masses and larvae.

TS-7 is a modified wetland area used as a retention basin. It is also known as "Weaver Road Pond" or "Blue's Pond" and receives surface runoff from a man-made channel. The presence of adult salamander, egg masses, and larvae confirm that this retention basin provides breeding habitat for tiger salamanders. There is limited egg mass attachment, which does not seem to affect the use of this pond for production. There is some potential for road mortality during periods of salamander migration, and the basin receives runoff from a drainage ditch. Routine analyses of storm water runoff done during the year can be used to determine whether water quality in this pond is affected. The road adjacent to this pond has been blocked off to vehicular traffic because of occasional flooding. Blocking this road has prevented road kills, especially during the breeding season. This pond is routinely used for tiger salamander research to determine the timing and directional variation of emergence. Annual surveys will continue.

TS-8 is a coastal plain pond. The presence of males, females, and egg masses indicates that this pond provides a suitable habitat for tiger salamanders. This pond will continue to be surveyed for egg masses, larvae, and adults.

TS-9 is a sedge depression that becomes an elongated vernal pool by seasonal flooding. Presence of egg masses and larvae indicates that this pond may periodically (in wet years) provide a suitable habitat for tiger salamanders. This pond will continue to be surveyed for egg masses, larvae, and adults.

TS-10 is a man-made retention basin. The basin receives run-off and once-through non-contact cooling water from a large drainage ditch. This basin, until recently, had the potential of drying up and as such would not allow larvae to metamorphose to adult salamanders. However, diversion of once-through non-contact cooling water to this basin has resulted in a continuous water source. As a result, limited emergent and submerged 
vegetation has begun to establish within the basin. This basin was modified in 2009 to increase the retention volume to accept increased storm water flows associated with the NSLS-II. In 2010, heavy flows from the NSLSII construction site carried significant amounts of silt to the basin, sealing the bottom preventing infiltration. The basin bottom will need to be scraped to allow infiltration and management of water levels at the correct depth for tiger salamanders.

TS-13 is a retention basin composed of two ponds. While the western most, larger basin allows rapid recharge with little potential for standing water, the eastern, smaller basin tends to retain water when used. Adult tiger salamanders were found in this basin; however, there was no evidence of egg masses or juveniles. In 2001 this basin contained water during the breeding season. While no egg masses were found, larvae were recovered in May 2001 as the basin began to dry down and were subsequently collected and transferred to a more permanent habitat. Because this basin may periodically be used for recharge of discharge waters, it will be managed as follows. If the basin is receiving, and retaining sufficient water for breeding from January through April, the water flow will be maintained through August of the year. If there is no water in the basin during breeding, then water may be diverted from this basin and flow terminated at any time for management purposes. This basin will continue to be included in annual surveys.

TS-13a (650 Sump) was created as part of the clean-up effort for the discharge lines and sump area. After cleanup the area was restored with native vegetation. The restoration was supposed to result in a recharge basin that would not hold water. The result, however, was a ponded area that immediately attracted tiger salamanders. Therefore this pond is now managed as tiger salamander habitat.

TS-15 is a small depression located within a larger surrounding wetland area. Egg masses have been noted both within the depression and throughout the surrounding wetland. Both the depression and the wetland contain suitable attachment sites for egg masses. This pond will continue to be monitored annually during field surveys.

TS-15a has historically acted as a population sink for tiger salamanders because the berms prevented infiltration of water from the surrounding wetlands as the pond dried down. In dry years the pond dried prior to metamorphosis. As part of the environmental benefits work related to the Long Island Solar Farm, BP Solar modified TS-15a based on plans approved by the NYSDEC.

TS-18a \&b are lined basins designed to capture sewage waters suspected of containing radiological or chemical contaminants above BNL's SPDES Permit limits. These two ponds, located at the east end of the Sewage Treatment Plant (STP), are lined with double plastic liners to prevent groundwater intrusion of potentially contaminated waters. Because the liners may tear or otherwise be damaged if not kept in place, several inches of water are maintained within the basins. This water is known to be a site of successful breeding by tiger salamanders, but the function of these ponds is protection of the Peconic River and groundwater from potentially harmful effluents. Therefore these ponds are not specifically managed for tiger salamanders, but every effort is made, in coordination with NYSDEC, to ensure the protection of larval tiger salamanders should transfer actions need to occur.

TS-19 \& TS-135 are small vernal pools that contain water only during years of high rainfall. When they do contain water they provide suitable habitat for tiger salamanders and egg masses have been detected in these ponds during wet years. These ponds will continue to be monitored annually.

TS-W3 is a vernal pool complex located in a large herbaceous wetland along the Peconic River within the RHIC ring. Presence of adult salamanders, egg masses, and larvae confirm this pool is a suitable habitat for tiger salamander breeding. However, this pond may receive road runoff from the William Floyd Parkway in wet years, as well as from the RHIC ring road. Much of the area contains sufficient egg mass sites on any given year. In most years this pond dries out prior to larval development. Annual surveys will continue to be conducted at this location. 
TS-W4 is a series of small vernal pools. Presence of egg masses and larvae confirm this site as a breeding site for tiger salamanders. However, the pools are extremely small, often less than 20 square $\mathrm{ft}$. of surface area and they tend to have high water temperatures and drying conditions prior to larval development. These small pools will likely be filled in as part of the Environmental Restoration program, but the adjacent TS-A7 pools will be upgraded to improve the habitat for tiger salamanders.

TS-A6a, TS-A6b, TS-A6c, TS-A6d and associated canal are all part of a recharge basin system receiving coolant water from facilities. Tiger salamander egg masses have been identified in the canal and at least one larval salamander has been documented in one of the ponds in 2000 and 2001. Historically, large numbers of fish were present in these ponds. Currently the ponds contain golden shiners that periodically die off due to drying conditions, high water temperatures, or low dissolved oxygen. The ponds are periodically maintained for recharge purposes. This maintenance activity will be coordinated to occur between August and December. TSA6d is a large basin added to the complex in 2002. The northern end of this basin is to be planted with native vegetation to encourage use by the tiger salamander. The sides and outer surfaces of this basin are to be planted with native grasses to reduce erosion. Annual surveys will continue to occur to document the use of these ponds and the associated canal by tiger salamanders.

TS-A7 contains two man-made retention basins lined with plastic. The presence of adult salamanders, egg masses, and larvae during surveys confirm this as a breeding pond for salamanders. These basins have consistently provided suitable habitat for reproduction. However, no larvae have been documented since 2000. This is probably due to high water temperatures, low dissolved oxygen, and drying conditions. The Environmental Restoration Program will be removing known contamination from these ponds, forming one pond in the area, and constructing the single pond specifically to enhance tiger salamander habitat.

TS-W6a is in a wetland area shaded by a dense tree canopy. The area contains a man-made channel as well as four naturally occurring vernal pools. Egg masses indicate that tiger salamanders use this wetland. This site will continue to be surveyed annually.

TS-W6b is a vernal pool located across from TS-W6a. The presence of adult salamanders, egg masses, and larvae confirms that this pool is a breeding site for tiger salamanders. However, the pond typically dries up before the larvae transform to sub-adults. This pool also contains contaminants and is scheduled for environmental cleanup in the near future, to improve water retention capabilities. The pool will continue to be surveyed annually for egg masses, larvae, and adults as appropriate.

\section{Unconfirmed Breeding Sites}

ts-3 and ts-17 are vernal pools located near confirmed tiger salamander habitats. Although the ponds appear to be undisturbed and have suitable habitat and ample egg attachment sites, no evidence of salamander use has been found. Because these ponds tend to be shallow and dry down, they are not likely to be suitable habitat except during the wettest years. These ponds will be surveyed when water is present during the breeding season. Ts-17a has been documented as containing tiger salamander egg masses in 2011. Verification of survival needs to occur in summer 2011.

ts-16 is composed of three recharge basins. Two smaller basins have been historically used for the discharge of cooling water associated with operations at Building 490. Those operations no longer occur and it is likely that these two basins will never receive sufficient water in the future to benefit tiger salamander breeding. The larger basin is currently being used for the discharge of water generated by a groundwater treatment system. The volume of water generated is sufficient to support tiger salamander breeding. However, the flow rates generated result in sufficient current to limit tiger salamander breeding. This basin is also maintained specifically to enhance groundwater recharge, thus the basin has few, if any, suitable spots for egg mass attachment. This basin will continue to be surveyed for use by tiger salamanders, and maintenance of the basin will be coordinated to occur between August and December. 
ts-11 was found to be suitable as a breeding site. However this pond is outside the jurisdiction of BNL and will not be managed under the NRMP, with the exception of complying with legal requirements should any actions be proposed in the area on BNL property.

ts-12 is composed of two ponds within a flooded forest depression resulting from the discharge of oncethrough, noncontact cooling water. The amount of discharge water has decreased over the years and typical water levels are only 1-2 inches in the cooler months. The majority of the ponds are dry during warmer months. It is not likely that this area is suitable for breeding, but it will continue to be surveyed for evidence of use by the salamanders.

ts-W2 is located within the fence of the Gamma Forest and is composed of several small ponds associated with the Peconic River. Persistent water and egg mass attachment sites make this site suitable for tiger salamanders. However, the persistent water and connection to the river also provides habitat suitable to support fish. This site will continue to be monitored to document the presence or absence of tiger salamanders.

ts-W5 is composed of two small ponds located north of Brookhaven Avenue near TS-W6b (a confirmed site). These pools hold water for extended periods only in wet years. The pool will be visited annually and surveyed only if it contains water during the breeding season.

ts-14 (Note: this pool was mistakenly included as a confirmed location under the Wildlife Management Plan. The designation has been changed from TS-14 to ts-14). This pool is located at the northeast corner of the sludge drying beds that were once part of the STP. The pond was likely used as a final settling basin for the WW I facility. The Peconic River flows into the pond on the west and exits the pond on the east. The depth of the pond is unknown but exceeds $6 \mathrm{ft}$. The depth of the pond has prevented the accurate survey for egg masses, larvae, and adults. It is not likely that this is suitable breeding habitat due to the presence of fish (brown bullhead, chain pickerel, etc.). 


\section{Appendix B - Protection of Threatened Fish}

\section{Introduction}

As indicated earlier, the banded sunfish (Enneacanthus obesus) and swamp darter (Etheostoma fusiforme), Figure B-1 and B-2, are listed as threatened within New York State. They are not, however, in any protection category with the federal government. The reason for state threatened status is that the only remaining populations of the banded sunfish and swamp darter in New York are in eastern Long Island and these sites are considered vulnerable to adverse environmental impacts. The habitat of these fish is primarily in slow water areas within lakes, ponds, and backwaters of streams and rivers (Breeder, 1936). Their preferred substrate is sand or mud, and other preferred areas are often shallow with vegetation over detritus-laden bottoms. Vegetation in these areas is dense enough to maintain a viable habitat for both fish.

\section{Protection or Enhancement of Threatened Fish Habitat}

The current water and vegetation conditions in the Peconic River and large ponds associated with the river on site support the requirements for successful habitation by banded sunfish and swamp darters, as observed during the exploratory and routine sampling of fauna by BNL and NYSDEC. The primary impacts on such habitats have been predominantly natural. For example, lower than normal rainfall followed by extended drought conditions has contributed to lowering of the water table, leading to decreased water-flow in the river and drying of ponds.

Given the above characteristics of the habitat of the banded sunfish, protection of threatened fish is based on the following actions:

- Eliminating, reducing, or controlling pollutant discharges. Discharges to the Peconic River are evaluated for pollution control at the source, as opposed to pollution control at the discharge point into the Sewage Treatment Plant (STP) or the recharge basins. BNL has a pollution prevention/process evaluation program that evaluates sources and develops and implements pollution prevention measures. Periodic reports are prepared on the pollution prevention program and progress.

- Upgrading the STP. This $\$ 8,000,000$ project has improved the treatment process (primary to tertiary), reduced nitrogen loading in the Peconic River, and eliminated the use of chlorine as a disinfectant. Full implementation of this project was completed in 1998 and has resulted in tertiary treatment of BNL's sewage.

- Maintaining an active environmental monitoring program for discharges to the river. Monitoring for organic, inorganic, radiological and biological parameters is conducted, in accordance with the State Pollutant Discharge Elimination System (SPDES) Permit. Figure B-3 depicts the locations of the monitoring stations. Effluent limitations in the permit are based upon a Class $C$ receiving water quality, which is based upon the protection of fish populations. The Whole Effluent Toxicity testing program has demonstrated that the discharges generally meet requirements for protecting fish populations.

- Ensuring that adequate flow of the river is maintained within areas currently identified as banded sunfish habitats (especially within the area from the STP outfall to about $500 \mathrm{ft}$. from the old site boundary, Station HM). This is achieved through routine observation of the river flow as part of the monitoring program. If discharges were to be eliminated or reduced in favor of groundwater discharge, a requirement to evaluate and address any major changes to the banded sunfish habitat will be imposed by NYSDEC during the permitting process. Creating deep pools at Station HM and HQ (Figure B-3), so that adequate volume of water is available to enable small fish, like the banded sunfish, to survive during droughts. Also, the addition of vegetation and other physical features that will promote the growth and sustenance of the Banded Sunfish population may be evaluated.

- Ensuring that existing vegetation in the sunfish habitat area is not disturbed. This is accomplished by 
reviewing all activities that are proposed in the Peconic River on site. If the selected environmentalrestoration remedy for the contaminated sediment in the Peconic River is excavation and removal, the extent and duration of any disturbance will be minimized as much as possible and the habitat should be restored when the project is completed.

- Continuing to monitor the banded sunfish population by routine sampling of the river in cooperation with NYSDEC's Fisheries Branch and Cold Springs Harbor Fish Hatchery and Museum. Population counts and size measurements are made during the sampling surveys.

- Reducing potential predator species. For example, pickerel and largemouth bass are removed during the fish-sampling program. A record of the number of pickerel and largemouth bass taken is logged at each sampling event to determine the success of controlling predators.

- Ensuring that on-going remediation efforts do not have an unacceptable impact on habitats. It is anticipated that the Peconic River may undergo a significant cleanup. A remedial system design is in progress involving proposals to dredge the sediment on site to remove contaminants. The final decision has not been made. However, it is understood that any remedial action must consider the impact on the flora and fauna of the Peconic River, and that the habitat of the banded sunfish will be factored into the final assessment of the cleanup operation.

- Restoration after natural disaster occurs. The swamp darter is known to exist at only one BNL location, Zeke's Pond. The population and water levels of this site are periodically evaluated to determine continued suitability for this fish. Unfortunately, the drought of 2002 resulted in the complete drying of this pond, with the subsequent loss of the swamp darter population inhabiting the area. Consultation with NYSDEC Freshwater Fisheries should discuss the implementation of a restoration project. 
Figure B-1. Banded sunfish.

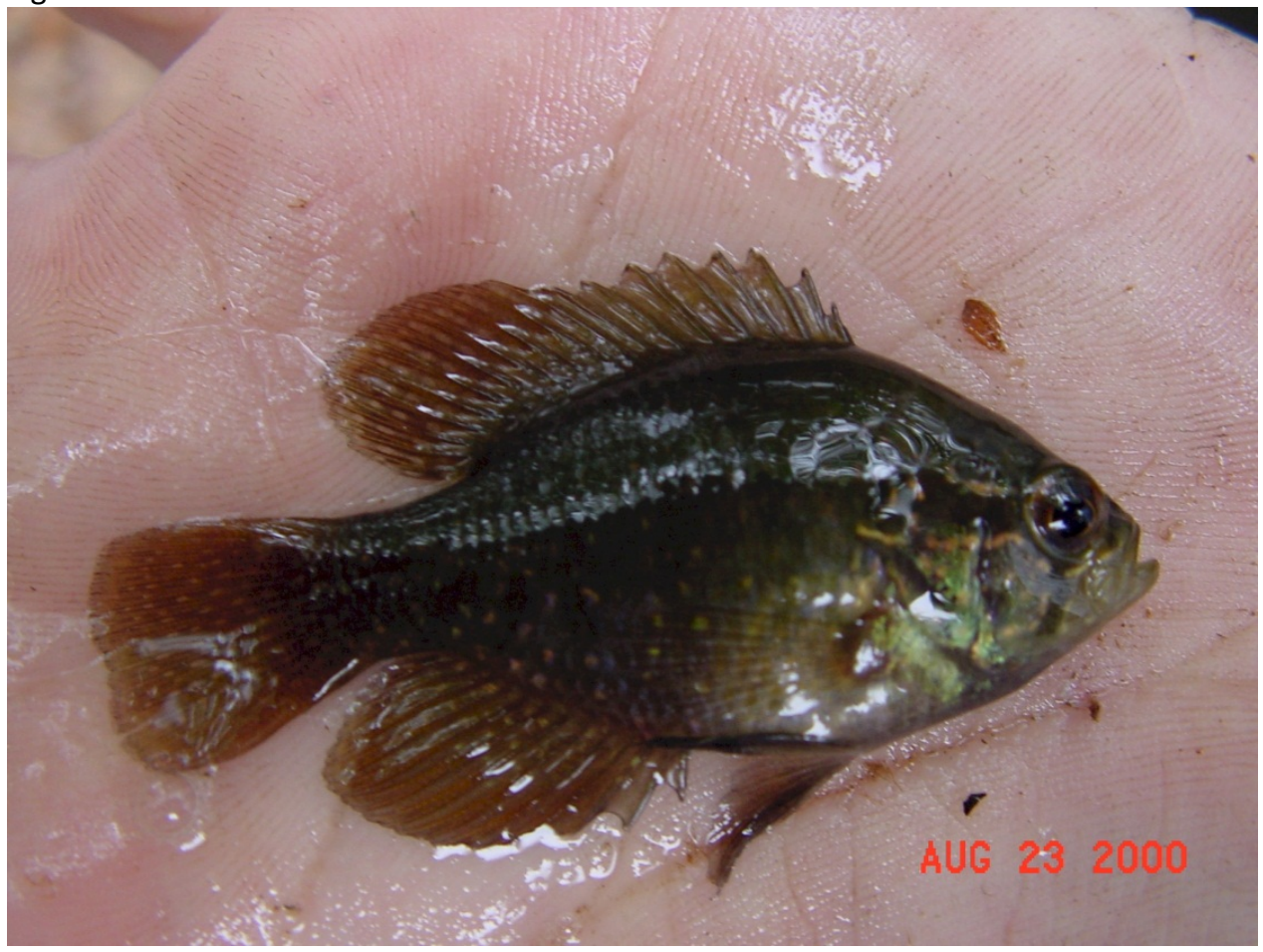

Figure B-2. Swamp darter.

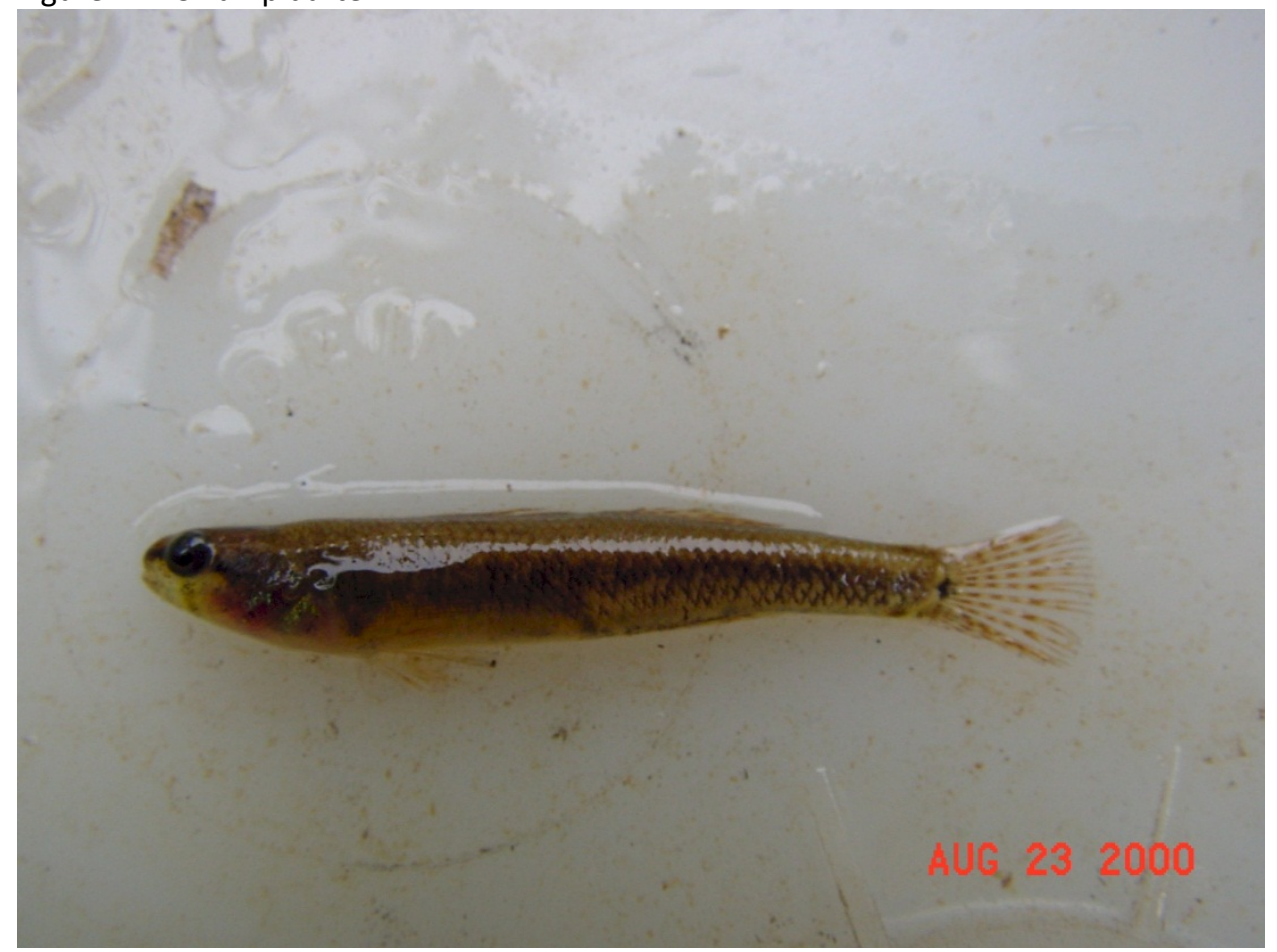


Figure B-3. Peconic River monitoring stations.

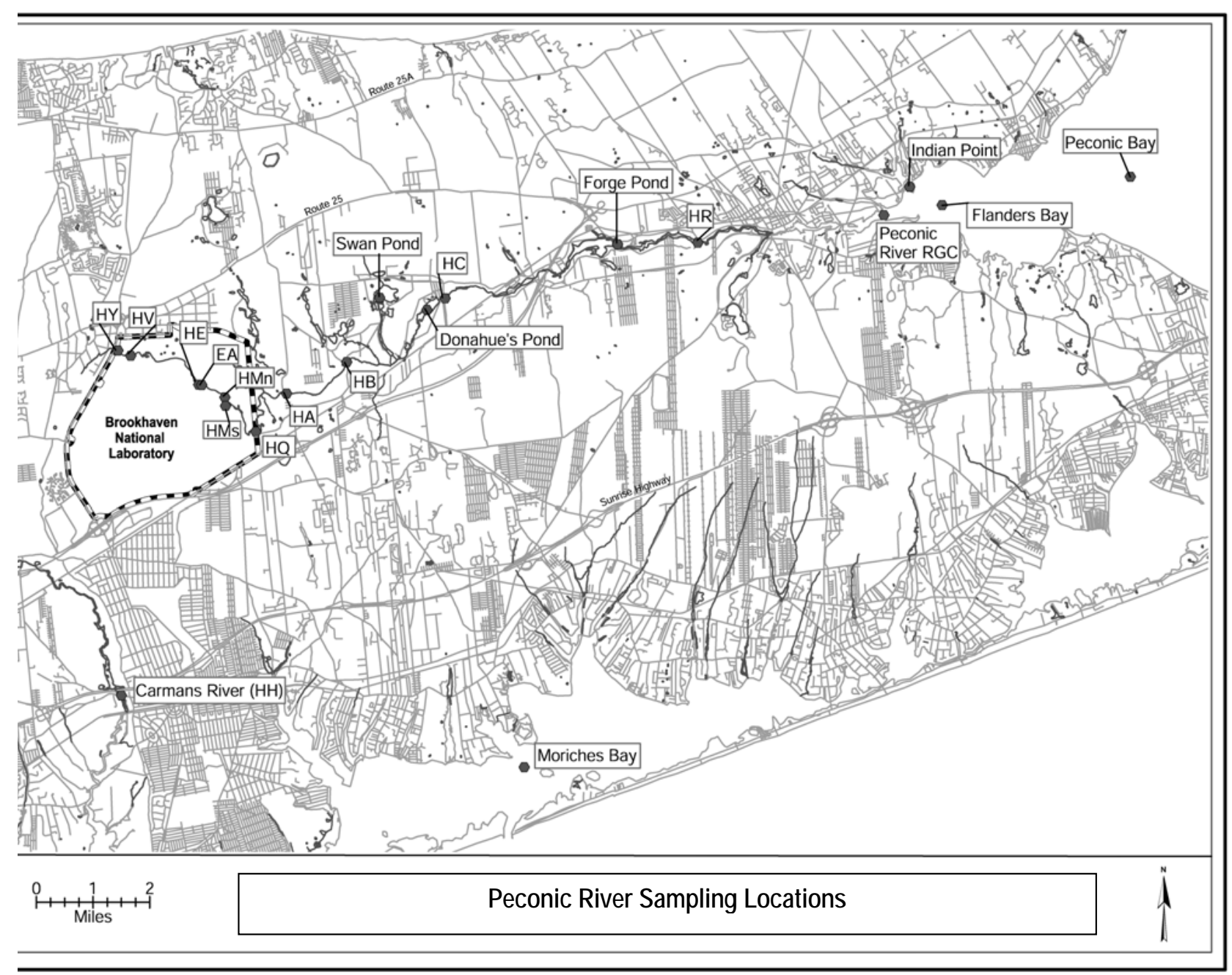




\section{Appendix C - Natural Resource Management Plan - Completed Action Items}

\begin{tabular}{|c|c|c|c|c|}
\hline $\begin{array}{l}\text { Action } \\
\text { Item }\end{array}$ & Site ID & Action & Planned Date & Action Taken \\
\hline 1 & Site-wide & Transition WMP Action into NRMP & December 2003 & Complete \\
\hline 3 & Site-wide & TAG Review of Annual Report & Annual by May & Discontinued \\
\hline \multicolumn{5}{|c|}{ Deer Management } \\
\hline 10 & Site-wide & $\begin{array}{l}\text { Issue and Discussion Paper on deer } \\
\text { management by Natural Resource } \\
\text { Manager }\end{array}$ & Fall 2007 & Completed, approved Feb. 2009 \\
\hline \multicolumn{5}{|c|}{ Tiger Salamander } \\
\hline 19 & RHIC & New pond being added at RHIC & Summer 2004 & Completed \\
\hline 20 & Tiger salamander & $\begin{array}{l}\text { Set up cover boards around one } \\
\text { breeding site (as a test case) }\end{array}$ & Summer & $\begin{array}{l}\text { Summer } 2001 \& 2002, \\
\text { completed, drift fences } \\
\text { installed, completed }\end{array}$ \\
\hline 21 & TS-A7 & Lining of pool ER program & Aug 2003 & Completed \\
\hline 22 & TS-W6b & Pond Remediation ER program & 2004-2005 & Completed \\
\hline & TS-10 & Expansion of pond to lessen slopes & 2006 & $\begin{array}{l}\text { Completed as part of NSLS-ii } \\
\text { project } 2008\end{array}$ \\
\hline \multicolumn{5}{|c|}{ Banded Sunfish } \\
\hline 23 & OU V & Peconic River Remediation Program & Spring 2004 & $\begin{array}{l}\text { Completed, tracking success of } \\
\text { restoration completed }\end{array}$ \\
\hline \multicolumn{5}{|c|}{ Frosted Elfin } \\
\hline 25 & Habitat Specific & $\begin{array}{l}\text { Establish standard monitoring protocols } \\
\text { for the Frosted Elfin }\end{array}$ & & Likely no longer needed \\
\hline \multicolumn{5}{|c|}{ Population Management } \\
\hline 36 & Site-wide & Manage Wild Turkey population & As necessary & Not yet necessary \\
\hline 37 & Site-wide & Establish BNL policy on feral animals & $\begin{array}{l}\text { General policy } \\
\text { implemented }\end{array}$ & Completed \\
\hline 38 & Site-wide & $\begin{array}{l}\text { Establish monitoring and management } \\
\text { protocols for feral animals }\end{array}$ & Fall 2003 & $\begin{array}{l}\text { Completed, initiated, ad hoc } \\
\text { group providing monitoring } \\
\text { information }\end{array}$ \\
\hline \multicolumn{5}{|c|}{ Vegetation Management } \\
\hline 39 & Site-wide & $\begin{array}{l}\text { Establish protocol for use of native } \\
\text { vegetation }\end{array}$ & & $\begin{array}{l}\text { Routinely done w/out protocol, } \\
\text { planting list provided }\end{array}$ \\
\hline 41 & RHIC Revegetation & Implement Revegetation & Completed & $\begin{array}{l}\text { Grasses planted } 2002 \text { and } 2003 \text {, } \\
\text { Completed } 2005 . \text { No active } \\
\text { revegetation needed as species } \\
\text { are colonizing on their own. }\end{array}$ \\
\hline 42 & Site-wide & $\begin{array}{l}\text { Establish policy and procedure for } \\
\text { cutting trees }\end{array}$ & & $\begin{array}{l}\text { Informal procedure appears } \\
\text { adequate. }\end{array}$ \\
\hline \multicolumn{5}{|c|}{ Ecosystem Monitoring and Management } \\
\hline 47 & Site-wide & $\begin{array}{l}\text { Develop criteria to monitor wetland } \\
\text { health }\end{array}$ & 2007 & Completed \\
\hline 50 & Site-wide & Develop criteria to monitor forest health & Fall 2004 & Completed 2005 \\
\hline 51 & Site-wide & $\begin{array}{l}\text { Establish forest health monitoring } \\
\text { locations }\end{array}$ & Summer 2005 & $\begin{array}{l}\text { Initiated } 2005 \text {, continued 2006, } \\
\text { completed }\end{array}$ \\
\hline \multicolumn{5}{|c|}{ Pesticide Use } \\
\hline 54 & Site-wide & $\begin{array}{l}\text { Determine need for a SBMS subject area } \\
\text { on pesticides }\end{array}$ & As necessary & Not currently necessary \\
\hline 55 & Site-wide & $\begin{array}{l}\text { Pesticide use for natural resource } \\
\text { management }\end{array}$ & As identified & Completed \\
\hline \multicolumn{5}{|c|}{ Wildland Fire Management } \\
\hline 56 & Site-wide & Implement Fire Management Plan & Sept. 2003 & $\begin{array}{l}\text { Plan approved September } \\
2003, \text { re-written in } 2009\end{array}$ \\
\hline 57 & Site-wide & $\begin{array}{l}\text { Implement use of prescribed fire and } \\
\text { mechanical fuel reduction }\end{array}$ & March 2003 & $\begin{array}{l}1^{\text {st }} \text { Fire November } 2004 \\
\text { CY2006 Approved. CY2007 plan } \\
\text { approved }\end{array}$ \\
\hline
\end{tabular}




\section{Appendix D - Natural Resource Management Plan - Ongoing and New Action Items}

\begin{tabular}{|c|c|c|c|}
\hline Site ID & Action & Planned Date & Action Taken \\
\hline Site-wide & Annual Summary Report & Annual by April 30 & Ongoing \\
\hline Site-wide & NRMP Plan Update & $\begin{array}{l}\text { Every } 5 \text { years } \\
\text { Next update } 2016\end{array}$ & In process \\
\hline Site-wide & Adapt Management based on new information & As Required & Ongoing \\
\hline Site-wide & $\begin{array}{l}\text { Maintain and Improve relationships with } \\
\text { stakeholders }\end{array}$ & Continual & Ongoing \\
\hline Site-wide & $\begin{array}{l}\text { Improve decision making through use of } \\
\text { innovative tools }\end{array}$ & As Necessary & Implemented 2003, ongoing \\
\hline \multicolumn{4}{|l|}{ GIS } \\
\hline Site-wide & $\begin{array}{l}\text { Develop \& maintain natural resource data layers } \\
\text { of GIS }\end{array}$ & Ongoing & Ongoing \\
\hline Site-wide & Use GIS to assist in mapping and planning & Ongoing & Ongoing \\
\hline Site-wide & Maintain meta-data on GIS data & Ongoing & Ongoing \\
\hline \multicolumn{4}{|c|}{ Cultural Resource Management } \\
\hline Site-wide & $\begin{array}{l}\text { Continue to develop \& maintain GIS layers } \\
\text { documenting cultural resources. }\end{array}$ & As required & Ongoing \\
\hline \multicolumn{4}{|c|}{ Freshwater Wetlands \& the Peconic River } \\
\hline Site-wide & Determine functionality of BNL Central wetlands & 2007-2009 & Not started \\
\hline Site-wide & Maintain or improve wetland functions & & \\
\hline Wetlands & $\begin{array}{l}\text { Explore implementation of monitoring protocols } \\
\text { at BNL }\end{array}$ & $\begin{array}{l}\text { As funds become } \\
\text { available }\end{array}$ & Not yet started \\
\hline $\begin{array}{l}\text { Monitoring } \\
\text { Station HMn }\end{array}$ & Monitor for flow \& water quality & $\begin{array}{l}\text { Monthly sampling } \\
\text { SPDES Program }\end{array}$ & Ongoing \\
\hline $\begin{array}{l}\text { Peconic } \\
\text { River } \\
\text { Remediation }\end{array}$ & Explore creating wildlife viewing areas & & \\
\hline $\begin{array}{l}\text { Peconic } \\
\text { River }\end{array}$ & $\begin{array}{l}\text { Evaluate removal of barriers to fish migration on } \\
\text { site }\end{array}$ & 2014 & Not yet started \\
\hline $\begin{array}{l}\text { Peconic } \\
\text { River }\end{array}$ & $\begin{array}{l}\text { Fish sampling with NYSDEC/Cold Spring Harbor } \\
\text { due to remediation }\end{array}$ & $\begin{array}{l}\text { Annual } \\
\text { Spring/Summer }\end{array}$ & Ongoing \\
\hline $\begin{array}{l}\text { Peconic } \\
\text { River }\end{array}$ & $\begin{array}{l}\text { Evaluate continued need for environmental } \\
\text { monitoring of fish should BNL move to onsite } \\
\text { recharge to groundwater system }\end{array}$ & 2014 & Not yet started \\
\hline \multicolumn{4}{|c|}{ Law Enforcement } \\
\hline Site-wide & Monitor ATV use and damage & Continual & Ongoing \\
\hline Site-wide & Work to reduce ATV use; investigate deterrents & Continual & Ongoing \\
\hline Site-wide & Work with security on other trespass issues & Continual & Ongoing \\
\hline \multicolumn{4}{|c|}{ Vegetation Monitoring \& Management } \\
\hline Site-wide & $\begin{array}{l}\text { Revisit forest health monitoring plots; collect } \\
\text { and analyze data }\end{array}$ & Every 10 years. & Ongoing \\
\hline Site-wide & $\begin{array}{l}\text { Establish Deer Exclosures associated with } 4 \\
\text { forest health plots }\end{array}$ & 2011 & Not yet started \\
\hline Site-wide & $\begin{array}{l}\text { Develop cooperative agreement with NYSDEC to } \\
\text { implement prescribed fire at BNL }\end{array}$ & 2012 & \\
\hline Site-wide & Implement Fire Management Plan & Sept. 2003 & $\begin{array}{l}\text { Plan approved September 2003, re-written in } \\
2009\end{array}$ \\
\hline Site-wide & $\begin{array}{l}\text { Implement use of prescribed fire and } \\
\text { mechanical fuel reduction }\end{array}$ & March 2003 & $\begin{array}{l}1^{\text {st }} \text { Fire November } 2004 \\
\text { CY2006 Approved. CY2007 plan approved }\end{array}$ \\
\hline $\begin{array}{l}\text { White pine } \\
\text { stands }\end{array}$ & $\begin{array}{l}\text { Investigate having timber companies come in to } \\
\text { thin stands-possibly for cost of lumber }\end{array}$ & & \\
\hline White pine & Investigate use of NY Incident Command and & & \\
\hline
\end{tabular}




\begin{tabular}{|c|c|c|c|}
\hline stands & $\begin{array}{l}\text { Wildland Fire Academy for management of } \\
\text { white pines }\end{array}$ & & \\
\hline Site ID & Action & Planned Date & Action Taken \\
\hline Site-wide & $\begin{array}{l}\text { Use native vegetation on restorations and new } \\
\text { construction landscaping }\end{array}$ & $\begin{array}{l}\text { As necessary and } \\
\text { applicable }\end{array}$ & Initiated 2003 , ongoing \\
\hline ISPZ & $\begin{array}{l}\text { Re-survey the current ISPZ, explore addition of } \\
\text { new areas to ISPZ and rewrite the ISPZ plan. }\end{array}$ & 2011-2012 & Not yet started \\
\hline Site-wide & Monitor distribution of invasive species & Continual & Ongoing; initiated Summer 2003 \\
\hline Site-wide & Manage invasive plants where possible & As necessary & Ongoing; initiated 2008 \\
\hline \multicolumn{4}{|c|}{ Habitat Enhancement - other species } \\
\hline Site-wide & $\begin{array}{l}\text { Maintain and monitor bird nests/boxes for } \\
\text { bluebirds, kestrel \& wood duck }\end{array}$ & Annually & Ongoing \\
\hline LISF & $\begin{array}{l}\text { Work with LISF to install nest boxes on-site once } \\
\text { construction is completed. }\end{array}$ & 2012 & Not yet started \\
\hline Site-wide & $\begin{array}{l}\text { Add nest box locations and other data to GIS } \\
\text { library. }\end{array}$ & As necessary & Not yet started \\
\hline \multicolumn{4}{|c|}{ Special Status Species - General } \\
\hline Site-wide & Maintain Special-status species list & Annual Review & Ongoing \\
\hline Site-wide & Identify habitats of special-status species & Continual & Ongoing \\
\hline \multicolumn{4}{|c|}{ Frosted Elfin } \\
\hline $\begin{array}{l}\text { Habitat } \\
\text { specific }\end{array}$ & Confirm presence/absence of Frosted Elfin & $\begin{array}{l}\text { May-June } \\
\text { Annually }\end{array}$ & Ongoing \\
\hline Site-wide & Habitat assessment for lupine & Spring 2004 & Ongoing \\
\hline $\begin{array}{l}\text { Species } \\
\text { specific }\end{array}$ & $\begin{array}{l}\text { Increase lupine population; maintain and } \\
\text { enhance lupine habitats }\end{array}$ & Continual & Ongoing \\
\hline \multicolumn{4}{|c|}{ Banded Sunfish \&Swamp Darter } \\
\hline Site-wide & $\begin{array}{l}\text { Monitor for banded sunfish and survey for } \\
\text { presence of swamp darter }\end{array}$ & Biennially & Ongoing \\
\hline Site-wide & Remove predatory fish & As necessary & Ongoing \\
\hline Site-wide & $\begin{array}{l}\text { Explore re-introduction of both species to on- } \\
\text { site portions of the river }\end{array}$ & As necessary & Ongoing \\
\hline \multicolumn{4}{|c|}{ Tiger Salamander } \\
\hline Site-wide & $\begin{array}{l}\text { TS annual egg mass \& larval surveys at breeding } \\
\text { ponds }\end{array}$ & $\begin{array}{l}\text { Annual Feb-April, } \\
\text { Jule-July }\end{array}$ & Ongoing \\
\hline \multicolumn{4}{|c|}{ Population Monitoring \& Management - other species } \\
\hline Site-wide & Conduct songbird surveys & $\begin{array}{l}\text { Annual April- } \\
\text { September }\end{array}$ & Ongoing \\
\hline Site-wide & Monitor turkey populations & Continual & Ongoing \\
\hline Site-wide & Provide NYSDEC with sighting reports & As necessary & Ongoing \\
\hline Site-wide & Cooperate with NYSDEC management actions & As necessary & Ongoing \\
\hline Site-wide & Monitor goose populations & Continual & Ongoing \\
\hline Site-wide & Manage goose populations by oiling eggs & As necessary & Ongoing \\
\hline Site-wide & Odonate surveys & Summers, periodic & Initiated 2003, periodic \\
\hline Site-wide & Reptile and amphibian surveys & Ongoing & Surveys are variable \\
\hline \multicolumn{4}{|c|}{ Deer Management } \\
\hline Site-wide & $\begin{array}{l}\text { Environmental Assessment under NEPA for deer } \\
\text { management }\end{array}$ & 2011 & In process \\
\hline Site-wide & Establish \& implement deer management & & $\begin{array}{l}\text { Decision to be made based on open } \\
\text { meetings }\end{array}$ \\
\hline Site-wide & Continue deer population estimation & $\begin{array}{l}\text { Nov-Jan } \\
\text { May-June }\end{array}$ & $\begin{array}{l}\text { Ongoing. Routine estimates made twice a } \\
\text { year, new protocol developed in } 2004\end{array}$ \\
\hline \multicolumn{4}{|c|}{ Feral \& Nuisance Animals } \\
\hline Site-wide & $\begin{array}{l}\text { Establish feral, free-ranging, nuisance animal } \\
\text { policy }\end{array}$ & & \\
\hline
\end{tabular}




\begin{tabular}{|c|c|c|c|}
\hline Site-wide & Implement BNL policy on feral animals & Continual & Ongoing \\
\hline Site ID & Action & Planned Date & Action Taken \\
\hline \multicolumn{4}{|c|}{ Climate Change } \\
\hline Site-wide & $\begin{array}{l}\text { Keep informed of LCC research findings and } \\
\text { management recommendations }\end{array}$ & Continual & Not yet started \\
\hline Site-wide & $\begin{array}{l}\text { Explore possibility of performing research on } \\
\text { local effects of climate change on site }\end{array}$ & 2012-2013 & Not yet started \\
\hline \multicolumn{4}{|c|}{ Education \& Outreach } \\
\hline Education & $\begin{array}{l}\text { Provide educational material or opportunities to } \\
\text { BNL staff and public on environmental issues }\end{array}$ & Continual & $\begin{array}{l}\text { Ongoing. Utilize Office of Education } \\
\text { Programs Interns, etc. }\end{array}$ \\
\hline Site-wide & $\begin{array}{l}\text { Continue to host interns to assist with and } \\
\text { conduct research on-site as part of BNL's Office } \\
\text { of Education summer programs. }\end{array}$ & Ongoing & Ongoing \\
\hline \multicolumn{4}{|l|}{ Research } \\
\hline Site-wide & Support and conduct research as needed & Ongoing & $\begin{array}{l}\text { FERN periodically supports research with } \\
\text { limited funds }\end{array}$ \\
\hline Site-wide & $\begin{array}{l}\text { Identify, attract, and support ecological research } \\
\text { at BNL }\end{array}$ & Ongoing & Coordinating with FERN \\
\hline
\end{tabular}

